Article

\title{
Improving of Cherry Fruit Quality and Bearing Regularity by Chemical Thinning with Fertilizer
}

\author{
Robert Kurlus, Krzysztof Rutkowski ${ }^{(D)}$ and Grzegorz P. Łysiak *(D) \\ Department of Dendrology, Pomology and Nursery Production, Poznan University of Life Science, \\ 60-594 Poznań, Poland; kurlus@up.poznan.pl (R.K.); krzysztof.rutkowski@up.poznan.pl (K.R.) \\ * Correspondence: glysiak@up.poznan.pl; Tel.: +48-61-848-79-46
}

Received: 27 July 2020; Accepted: 27 August 2020; Published: 29 August 2020

check for updates

\begin{abstract}
The study's objective was to evaluate the influence of thinning on the quality and regularity of yield of 'Regina' cherries grown on a dwarf Gisela 5 rootstock. The experiments were conducted in the years 2009-2012 in Western Poland. Trees were thinned using a chemical agent, ammonium thiosulphate (ATS), at doses of $20 \mathrm{~g}_{\text {ATS L L }}^{-1}, 30 \mathrm{~g}$ ATS L$^{-1}$ and $40 \mathrm{~g} \mathrm{ATS} \mathrm{L}^{-1}$, and by hand, and the results of chemical and hand thinning were compared with those obtained for unthinned trees. The course of weather conditions in winter and during flowering had a significant impact on yield. Chemical thinning is known to be an effective method to regulate fruiting of pome trees, but it can also be successful if applied to cherry trees, as reflected by the alternate bearing index, which was the lowest after applying ATS at a dose of $40 \mathrm{~g}$. ATS treatment improved fruit quality in full crop years. Thinning resulted in, among other things, larger and darker fruit and higher content of total soluble solids and titratable acidity. Treatment with $40 \mathrm{~g}$ ATS L ${ }^{-1}$ significantly stimulated the vegetative growth of trees.
\end{abstract}

Keywords: TSS; skin colour; thinning of flowers; fruit quality; firmness; ammonium thiosulphate; tree vigour

\section{Introduction}

Sweet cherries are among fresh fruits that have been experiencing a global growth in production and trade [1]. According to 2017 data, global cherry production was 2,443,407 t (FAOSTAT). The world's largest producers were Turkey, the United States, Iran and Uzbekistan, which account for about $54 \%$ of the global cherry production. Italy and Spain are the largest cherry producers in Europe, while Chile is South America's top producer. In Poland, cherry production is about 20,000 t per year, and is increasing due to the intensification of fruit growing.

The use of dwarf rootstocks in the cultivation of cherries contributes to the intensification of production [2,3]. It increases productivity per area unit, but often leads to a deterioration in fruit quality [4]. Competition and market requirements force attention to quality and favour large, firm and high-sugar fruit $[5,6]$. The key to obtaining fruit with the proper and desired quality characteristics is the regulation of fruiting $[7,8]$. Trees that produce too much fruit due to the limited supply of carbohydrates and nutrients produce small fruit with a low firmness [9].

The use of dwarf rootstocks for cultivars with a tendency to yield small fruit significantly worsens the fruit size. This is especially evident in self-fertile cultivars, such as 'Lapins', 'Sweethart', which tend to create a large number of flower buds. With a large fruit set and weak tree growth, there is a problem with the right size of the fruit [10]. This dependence was found when assessing the Tabel ${ }^{\circledR}$ Edabriz dwarf rootstocks for cherries and the 'Summit' trees grafted on them. Removing $30 \%$ to $50 \%$ of fruit spurs resulted in the best fruit quality $(>28 \mathrm{~mm})$ [11]. The optimum quality of cherry fruit was achieved with 10 fruit per $\mathrm{cm}^{2}$ of limb cross-sectional area [6]. The ratio of leaves to fruit is also 
important. An increase in the leaves-to-fruit ratio is associated with an increase in the mass and content of the extract and an increase in the ratio of sugars to acids. With a larger area of the leaves per fruit, the colour of the fruit was darker and the fruit itself matured earlier [12]. It is important to develop cultivation methods that will allow growers to obtain an acceptable yield while maintaining high quality of fruit $[6,9,13]$.

Colour measurements enable easy assessment of the relative levels and changes in the content of anthocyanins in cherries [14]. Cherry fruit colour was also found to be related to the content of bioactive compounds in fruit [15]. Prices on the cherry market are associated with fruit colour attributes. The correlation between fruit colour and prices on Poznan-Franowo (Poland) wholesale market in 2007 and 2011 was significant [1]. This clearly demonstrates the importance of colour in evaluating fruit quality and in commerce.

Fruit thinning is a practice commonly applied in fruit growing [16]. Depending on the fruit species, chemical, manual or mechanical thinning is used. Mechanical thinning is an alternative to manual thinning, which is a laborious process [17] and which is increasingly difficult to apply from year to year due to the shrinking availability of workforce [18-20]. Mechanical thinning is typically applied to apples, pears and peaches [21,22]. However, the first devices were designed for the treatment of trees trained as narrow spindle axis, or fruit-bearing wall rather than for trees maintained in a broad spindle or vase shape [23]. Even if grown on dwarf rootstocks, cherry trees generally develop large crowns, comparable with apples and pears trees grown on seedling rootstocks; therefore, the thinning of cherries with the same devices as those used for apples or pears is very difficult and often impossible. This drawback can be solved by hand-held mechanical devices which can be applied to trees trained according to various systems [17], but fruit thinning with hand-held devices requires much more effort than chemical thinning and its efficiency is disputable, so it seems that the best solution is to work out an effective chemical thinning method.

Chemical thinning of fruit to improve its quality and prevent alternate bearing is commonly used in apple and pear cultivation $[13,24]$. It also reduces manual effort. Hand thinning of sweet and sour cherries is unprofitable due to labour intensity $[25,26]$. Compared to the pome species, more flowers must be left on the trees of stone species in order to obtain a profitable commercial yield of good quality. For peaches, this should be about $25 \%$ [27], while sweet and sour cherries require $75 \%$ flowers to remain on trees for a profitable commercial yield [28].

The options of chemical thinning of stone fruit are limited [29]. Tests have been conducted on thinning methods, such as blossom burning formulations, growth regulators and photosynthesis inhibitors $[30,31]$. Chemical thinning may be carried out during flowering or shortly thereafter to reduce the load on trees during the growing period [32]. Removing flowers and fruitlets in the initial growth period preserves more assimilates thus reducing competition between the vegetative and generative organs of the tree. This contributes to stronger vegetative growth but also stimulates the differentiation of flower buds and improves fruit quality and yield size [5].

Fruiting can be regulated using gibberellic acid (GA3) to reduce flower bud induction, balance the amount of fruit and improve fruit quality during the post-application season $[30,33]$. Gibberellin used during the initiation of flower buds in the induction period reduces the total number of flowers in the next growing season. The date of use is important, as bud development can be influenced only for a limited period each year. Thus, the period of induction and differentiation of flowers must be known for each species or for each cultivar [33,34]. Apart from Gibberellin, molasses, potassium soap, Tergitol, $2-4 \%$ vegetable oil emulsion, or copper were also tested as cherry thinning agents $[35,36]$.

One disadvantage of thinning flowers is the risk of yield loss if frosts and unfavourable conditions for pollination and fertilization occur after thinning. Chemicals such as ammonium thiosulphate (ATS), urea, hydrogen cyanamide and other sulphur-based compounds $[25,36,37]$ used in such conditions cause damage to the stigma, style, anther and pollen, which prevents pollination of damaged flowers.

ATS is used to thin apple and peach flowers and is considered to be ecologically sustainable. However, it can have phytotoxic effects on leaves and, consequently, reduce photosynthesis, which 
may affect the fruit size [37]. However, there are also reports that there are no visible signs of leaf damage caused by the use of $20 \mathrm{~g} \mathrm{~L}^{-1}$ ATS [38]. Two-percent ATS was used twice to thin the cherries of the 'Bing' cultivar grown on the 'Gisela 5' rootstock, for the first time when 10\% of flowers were developed and again when $90 \%$ of flowers were fully open. The result was a reduction in yield and improved fruit quality. In other studies, ATS effectively reduced the yield of cherries, but did not improve the fruit mass or size or the extract content [37].

In the context of the aforementioned findings, the aim of the work was to examine the impact of ATS on productivity parameters and the regularity of fruiting of 'Regina' cherry trees grown on a dwarf 'Gisela 5' rootstock. The study also assessed how thinning using ATS affects tree growth and fruit quality.

\section{Materials and Methods}

The study was conducted during the 2009 through 2013 growing seasons. The experimental field part was carried out in an orchard in western Poland, in an area situated at 52 $5^{\prime} 3-36^{\prime \prime}$ north latitude and $15^{\circ} 50^{\prime} 5-58^{\prime \prime}$ east longitude. The experimental material consisted of cherry trees of the 'Regina' cultivar grown on a 'Gisela 5' rootstock, planted as one-year old trees in spring 2001 in north-south rows with $3.5 \times 2.0 \mathrm{~m}$ spacing. The pollinator cultivar was 'Kordia', growing in blocks evenly distributed in the orchard, each block consisting of 4-6 trees. The experiment was set up in a randomized block design with 4 repetitions per each combination. There were four trees in each repetition, i.e., a total of 16 tress per combination. Each repetition was separated from the next one by two divider trees.

The following thinning treatments were applied in each year of the study (Table 1):

1. Control (C);

2. Flower thinning with ammonium thiosulphate solution at a dose of $20 \mathrm{~g} \mathrm{ATS} \mathrm{L}^{-1}$;

3. Flower thinning with ammonium thiosulphate solution at a dose of $30 \mathrm{~g}$ ATS $\mathrm{L}^{-1}$;

4. Flower thinning with ammonium thiosulphate solution at a dose of $40 \mathrm{~g} \mathrm{ATS} \mathrm{L}^{-1}$;

5. Fruitlet hand thinning (HT).

Table 1. Dates of thinning of 'Regina' sweet cherry trees in 2009-2012.

\begin{tabular}{ccccc}
\hline Treatment & \multicolumn{4}{c}{ Dates of Thinning Treatments } \\
\hline Control & $\mathbf{2 0 0 9}$ & $\mathbf{2 0 1 0}$ & $\mathbf{2 0 1 1}$ & $\mathbf{2 0 1 2}$ \\
\hline Flower thinning with 20 g ATS & 22.04 & 27.04 & 22.04 & 26.04 \\
\hline Flower thinning with 30 g ATS & 22.04 & 27.04 & 22.04 & 26.04 \\
\hline Flower thinning with 40 g ATS & 22.04 & 27.04 & 22.04 & 26.04 \\
\hline Fruitlet hand thinning & 30.05 & 01.06 & 28.05 & 30.05 \\
\hline
\end{tabular}

Crystalline 98\% ammonium thiosulphate (Rosier S.A., Moustier, Belgium) was used for chemical thinning treatments (Rosier S.A., Moustier, Belgium). Canopy spraying was performed with a Stihl SR420 sprayer at a working liquid dose of $0.35 \mathrm{~L}^{-1} \mathrm{e}^{-1}\left(500 \mathrm{~L}\right.$ of liquid ha $\left.{ }^{-1}\right)$. Chemical thinning of flowers was performed in the $80 \pm 6 \%$ open flower buds phase [38]. The date was set annually by monitoring the percentage of flowers developed on marked indicator branches of two trees in each treatment. At the time of chemical thinning, the mean percentage of developed flowers was $78.4 \%$ in $2009,83.3 \%$ in $2010,85.6 \%$ in 2010 and $76.6 \%$ in 2012.

Manual thinning of fruitlets was performed when their diameter was between $8 \mathrm{~mm}$ and $12 \mathrm{~mm}$. Fruitlets were removed from all branches of a tree where their number exceeded 100 fruitlets $\mathrm{m}^{-1}$ of the shoot length or 4 fruitlets per spur. The percentage of removed fruitlets depended on the number of 
set fruit and was determined each time by comparing the number of fruitlets on the marked indicator branches on each tree before and after thinning.

\subsection{Agricultural Practices}

The trees were trained as spindle crowns [39]. The height of the trees was limited to $3.30 \mathrm{~m}$ from the ground. The trees were pruned after fruit harvests, with the focus on stimulating vegetative growth by either removing older weakly growing shoots or shortening them to over ten centimetre long stumps. The trees grew in herbicide strips, while the inter-rows were covered with grass which was regularly cut. The trees were protected against diseases and pests in accordance with recommendations for commercial orchards.

Course of Meteorological Conditions

Climatic conditions were monitored using U12-011 sensors (Onset, Bourne, MA, USA) located in the tree crown at a height of $1.5 \mathrm{~m}$ from the ground level. Temperature and relative humidity were measured at a frequency of 24 readings per day. In addition, data from the weather station located in the orchard were analysed (Table 2).

Table 2. Air temperatures in experimental plot at bloom time in 2009-2012.

\begin{tabular}{|c|c|c|c|c|c|c|c|c|}
\hline & \multicolumn{2}{|c|}{2009} & \multicolumn{2}{|c|}{2010} & \multicolumn{2}{|c|}{2011} & \multicolumn{2}{|c|}{2012} \\
\hline & Day & Night & Day & Night & Day & Night & Day & Night \\
\hline $\begin{array}{l}\text { Mean air temperature } \\
\text { during bloom period }\end{array}$ & 15.6 & 8.1 & 12.8 & 9.0 & 16.7 & 8.2 & 20.3 & 11.8 \\
\hline $\begin{array}{c}\text { Mean air temperature } \\
\text { during } 7 \text { days after bloom }\end{array}$ & 15.2 & 7.9 & 13.2 & 10.1 & 19.1 & 6.4 & 17.1 & 10.8 \\
\hline $\begin{array}{l}\text { Minimum air temperature } \\
\text { during bloom period }\end{array}$ & -0.2 & 0.3 & 3.3 & 2.5 & -0.6 & -2.8 & 2.5 & 2.0 \\
\hline $\begin{array}{l}\text { Minimum air temperature } \\
\text { during } 7 \text { days after bloom }\end{array}$ & 2.0 & 2.9 & 5.8 & 5.0 & -0.6 & -2.4 & 4.6 & 3.7 \\
\hline $\begin{array}{l}\text { Maximum air temperature } \\
\text { during bloom period }\end{array}$ & 29.1 & 16.0 & 27.1 & 16.4 & 27.5 & 16.4 & 33.6 & 19.4 \\
\hline $\begin{array}{l}\text { Maximum air temperature } \\
\text { during } 7 \text { days after bloom }\end{array}$ & 27.5 & 13.7 & 21.0 & 17.1 & 30.7 & 15.2 & 32.8 & 18.7 \\
\hline
\end{tabular}

\subsection{Tree Vegetative Growth Parameters}

The following effects of experimental treatments were evaluated:

1. Percent of set fruit that dropped prematurely (\%).

2. Ratio of developed fruit to the number of flowers (\%).

In phenological stage BBCH 73 (second fruit fall), the number of fruitlets dropped was determined. In stages $\mathrm{BBCH} 81$ (beginning of fruit colouring) to BBCH 85 (colouring advanced), the share of fully developed fruit in the number of flowers was calculated. Measurements were conducted on one indicator branch within each tree.

\section{Assessment of Frost Damage of Flower Buds and Flowers}

Spring frosts occurred in April 2009 and May 2011, while in February 2012 there were frosts causing damage to buds. Figures 1 and 2 show the temperature changes. Damaged buds or flowers were counted each time after frost occurred. 


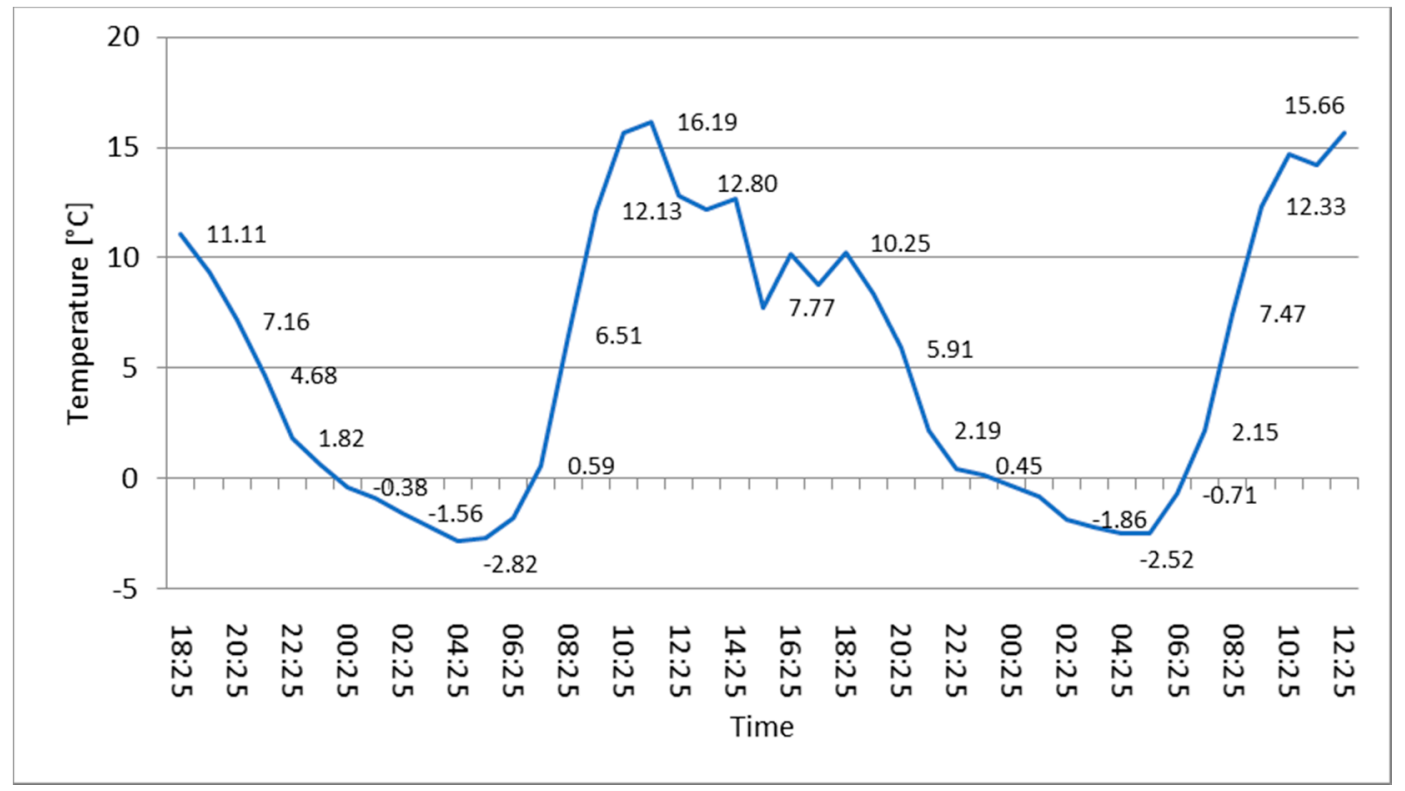

Figure 1. Air temperature fluctuations measured at $1.5 \mathrm{~m}$ height from 3 to 5 May 2011.

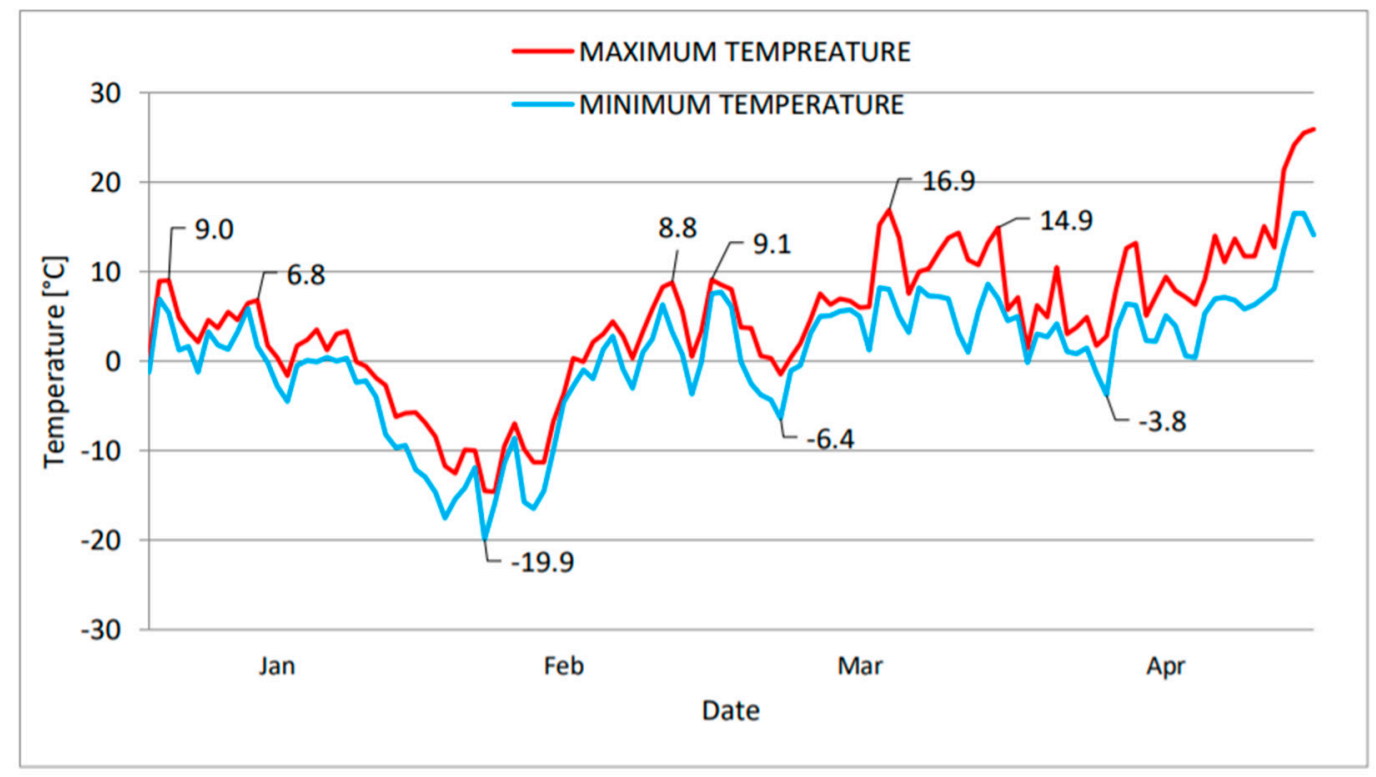

Figure 2. Minimum and maximum temperatures from January to April 2012.

\subsection{Yield and Tree Productivity Parameters}

The assessment of tree productivity between 2009 and 2012 was based on yield per tree $\left(\mathrm{kg}^{-1} \mathrm{e}^{-1}\right)$, yield per area unit $\left(\mathrm{t} \mathrm{ha}^{-1}\right)$, yield relative to the trunk cross-sectional area $\left(\mathrm{kg} \mathrm{cm}^{-2}\right)$ (yield efficiency), yield relative to the total length of one-year shoots $\left(\mathrm{kg} \mathrm{m}^{-1}\right)$ and the yield regularity index (alternate bearing index-ABI). The alternate bearing index was calculated from the formula proposed by [40] for different fruit species:

$$
A B I=\frac{\sum_{t=2}^{n}\left(y_{t}-y_{t-1}\right) /\left(y_{t}+y_{t-1}\right)}{n-1}
$$

where $n$-number of years; $y_{t}$-yield over the years.

The alternate bearing index of 0 thus expresses the regular yield, while its value close to 1 indicates completely alternating yield, with a full crop in one year and zero yield in the next. All fruit was harvested at the same time. The harvest date was based on the fruit skin colour: fruit was collected 
when most of it reached colour fraction No 4-5 according to the CTIFL colour scale (Centre Technique Inter professionnel des Fruit et Legumes, Paris, France) [41]. Harvest was carried out on 11 July 2009, 21 July 2010, 28 June 2011 and 15 July 2012. After harvest, the fruit with stalks was weighed from each tree to an accuracy of $0.01 \mathrm{~kg}$.

\section{Assessment of Fruit Quality and Tree Vegetative Growth}

The division of yield into quality fractions was based on measurements of the cross-sectional diameter (in a plane perpendicular to longitudinal axis) and the firmness of the fruit. Measurements were made with a Firmtech 2 (Bioworks, Victor, NY, USA) Fruit Firmness Tester, with an accuracy of $0.01 \mathrm{~g}$ for firmness and $0.01 \mathrm{~mm}$ for diameter measurement. The study was conducted in four repetitions, each time on 100 randomly selected fruit with stalks meeting the quality requirements for commercial fruit (no damage, diameter over $23.0 \mathrm{~mm}$ ). The measurement was made at room temperature on the fruit of each repetition. The result was expressed in $\mathrm{g} \mathrm{mm}^{-1}$, where firmness was determined as the force needed to bend the skin by $1 \mathrm{~mm}$.

The size results are given by specifying the percentage of fruit in the following size categories (diameter):

- $\quad$ below $22.0 \mathrm{~mm}$;

- from $22.0 \mathrm{~mm}$ to $24.0 \mathrm{~mm}$;

- $24.0 \mathrm{~mm}$ to $26.0 \mathrm{~mm}$;

- $26.0 \mathrm{~mm}$ to $28.0 \mathrm{~mm}$;

- $28.0 \mathrm{~mm}$ to $30.0 \mathrm{~mm}$;

- $\quad$ over $30.0 \mathrm{~mm}$.

The above-mentioned division into quality fractions assumes that fruit with a diameter of more than $28.0 \mathrm{~mm}$ is 'premium class' class fruit. The mean weight was assessed on the basis of mass measurements of 200 cherries with stalks from each repetition. Accuracy was up to $0.01 \mathrm{~g}$.

Fruit soluble solids (TSS) and titratable acidity (TA) were measured in the juice of 40 randomly selected cherries in each repetition. TSS content was evaluated using a refractometer PR-101a (Atago Co. Ltd., Fukaya-shi, Japan). TA was marked by adding $45 \mathrm{~mL}$ of distilled water to $5 \mathrm{~mL}$ of juice, titrating $0.1 \mathrm{~N}$ with sodium hydroxide to $\mathrm{pH}$ 8.2. TA was expressed as a percentage of malic acid [42].

Fruit skin colour was measured using a CR20 colorimeter (Konica-Minolta, Tokyo, Japan) on a sample of 40 cherries in each repetition. The results are presented in the form of a CIE Lab coordinates of the $L^{*} a^{*} b^{*}$ colour space and $h^{\circ}$. The value of hue angle $\left(h^{\circ}\right)$ is calculated from the formula:

$$
\mathrm{H}^{\circ}{ }_{\mathrm{ab}}=\tan ^{-1}\left(\mathrm{~b}^{*} / \mathrm{a} *\right)
$$

The growth strength of trees was assessed based on the length of one-year shoots. The measurement included all shoots exceeding $5.0 \mathrm{~cm}$ in length on two trees in each repetition between 2009 and 2012 . The measurement accuracy was $1.0 \mathrm{~cm}$. The growth strength was also determined by counting the mean number of 1 year shoots per tree and calculating the mean shoot length and the total length of all 1 year shoots. In addition, the circumference of the trunks was measured at a height of $20 \mathrm{~cm}$ from the ground surface and was converted into trunk cross-sectional area (TCSA). All measurements were taken after the vegetation period.

\subsection{Climatic Conditition}

The total annual rainfall figures varied considerably during the study period. In 2009 and 2011, the total annual rainfall was $573.5 \mathrm{~mm}$ and $574.0 \mathrm{~mm}$, respectively, whereas it exceeded $700 \mathrm{~mm}$ in the remaining years. In 2009, which was the driest year, the total rainfall was $265.4 \mathrm{~mm}$ during the growing season (April-September). Precipitation was distributed very unevenly within individual years. In 2011, the total rainfall was $0.8 \mathrm{~mm}$ in November and $198.7 \mathrm{~mm}$ in July. The coldest year 
was 2010, with a mean annual temperature of $7.7^{\circ} \mathrm{C}$. The lowest temperatures were recorded in January 2010 and February 2012, with the lowest temperature recorded below $-20^{\circ} \mathrm{C}$. In 2012, winter damage occurred in February after a warmer spell in January, when the temperature reached $9.0^{\circ} \mathrm{C}$ (Figure 2, Table 3).

Table 3. Recorded temperatures and total rainfall in 2009-2012.

\begin{tabular}{|c|c|c|c|c|c|c|c|c|c|c|c|c|}
\hline \multirow{3}{*}{ Month } & \multicolumn{4}{|c|}{ Total Rainfall (mm) } & \multicolumn{8}{|c|}{ Temperature $\left({ }^{\circ} \mathrm{C}\right)$} \\
\hline & \multirow[b]{2}{*}{2009} & \multirow[b]{2}{*}{2010} & \multirow[b]{2}{*}{2011} & \multirow[b]{2}{*}{2012} & \multicolumn{2}{|c|}{2009} & \multicolumn{2}{|c|}{2010} & \multicolumn{3}{|c|}{2011} & \multirow{2}{*}{$\frac{2012}{\text { Min. }}$} \\
\hline & & & & & $\bar{X}$ & Min. & $\bar{X}$ & Min. & $\bar{X}$ & Min. & $\bar{X}$ & \\
\hline Jan & 30.9 & 38.2 & 32.9 & 66.2 & -2.7 & -18.6 & -6.5 & -20.2 & 0.3 & -9.8 & 0.5 & -13.1 \\
\hline Feb & 44.6 & 17.1 & 13.6 & 35.7 & -0.7 & -7.2 & -1.1 & -8.9 & -2.4 & -16.1 & -3.7 & -20.0 \\
\hline Mar & 66.5 & 43.6 & 36.1 & 12.0 & 4.0 & -5.1 & 3.9 & -9.4 & 4.7 & -6.1 & 6.6 & -6.4 \\
\hline Apr & 15.1 & 26.9 & 16.0 & 36.1 & 12.7 & 0.8 & 9.3 & 0.6 & 12.2 & 2.8 & 9.3 & -3.8 \\
\hline May & 86.7 & 101.0 & 35.3 & 50.6 & 13.9 & 4.0 & 11.2 & 3.9 & 14.7 & 0.8 & 15.4 & 3.2 \\
\hline Jun & 73.1 & 10.4 & 44.1 & 114.0 & 15.2 & 5.8 & 17.6 & 7.9 & 18.4 & 9.9 & 15.9 & 6.0 \\
\hline Jul & 51.5 & 96.0 & 198.7 & 174.0 & 19.0 & 10.2 & 22.0 & 12.2 & 17.5 & 8.6 & 19.0 & 8.5 \\
\hline Aug & 10.2 & 106.1 & 53.2 & 54.0 & 19.8 & 8.2 & 18.0 & 10.3 & 18.4 & 8.0 & 19.1 & 10.2 \\
\hline Sep & 28.8 & 117.4 & 44.5 & 41.5 & 15.8 & 5.8 & 12.4 & 4.9 & 15.8 & 7.4 & 14.6 & 4.6 \\
\hline Oct & 68.1 & 10.0 & 35.0 & 21.5 & 7.1 & 0.1 & 6.9 & -0.9 & 9.7 & -1.3 & 8.5 & -3.5 \\
\hline Nov & 42.6 & 122.6 & 0.8 & 62.2 & 6.6 & -2.7 & 4.7 & -9.4 & 4.0 & -2.9 & 4.8 & -3.2 \\
\hline Dec & 55.4 & 59.9 & 64.0 & 34.3 & -1.2 & -16.0 & -5.5 & -15.7 & 3.3 & -2.7 & -0.8 & -12.8 \\
\hline Total & 573.5 & 749.1 & 574.0 & 702.1 & & & & & & & & \\
\hline
\end{tabular}

All data were statistically analysed. One or two-factor analysis of variance was carried out in accordance with the experiment design, using Statistica v. 13.3 (TIBCO Software Inc., Palo Alto, CA, USA). The differences between mean values were checked for statistical significance using Duncan's test, at a significance level $\alpha=0.05$. Correlation factor scans and determination analysis were done using Microsoft Excel tools Office 365.

\section{Results and Discussion}

\subsection{Effect of Thinning on Yield and Productivity}

Tree yield depended on the year of research and averaged between $2.14 \mathrm{~kg}^{\mathrm{tree}}{ }^{-1}$ in 2011 and $12.66 \mathrm{~kg} \mathrm{tree}^{-1}$ in 2009 (Figure 3). Yield variability was caused by low temperatures during flowering and fruit set. The $75.6 \%$ decline in yields in 2010 was due to poor pollination and flower fertilization, which was confirmed by fruitlet drop by as much as $82.0 \%$ (Figure 4 ). Honey bees, which pollinate most flowers in orchards, are not active at temperatures below $12{ }^{\circ} \mathrm{C}$ [43]. The optimum temperature for flower fertilization is about $20^{\circ} \mathrm{C}[44,45]$. In the following year (2011), low yield was likely caused by frosts of $-2.82{ }^{\circ} \mathrm{C}$ immediately after flowering (Figure 1 ). The mean share of frozen fruitlets was $95.0 \%$. Cherry buds and flowers are often damaged by spring frosts, which limit the areas of cherry cultivation [46]. Lethal temperatures for stages from green bud to full flowering range from $-5{ }^{\circ} \mathrm{C}$ to $-2{ }^{\circ} \mathrm{C}$ depending on the cultivar [47]. Temperature drops below $0{ }^{\circ} \mathrm{C}$ result in flower mortality of almost $80 \%$. Flower mortality depends on cultivar and late cultivars are considered to be less susceptible to damage [48]. However, in our study on 'Regina', which is a late cultivar, the damage was significant. 


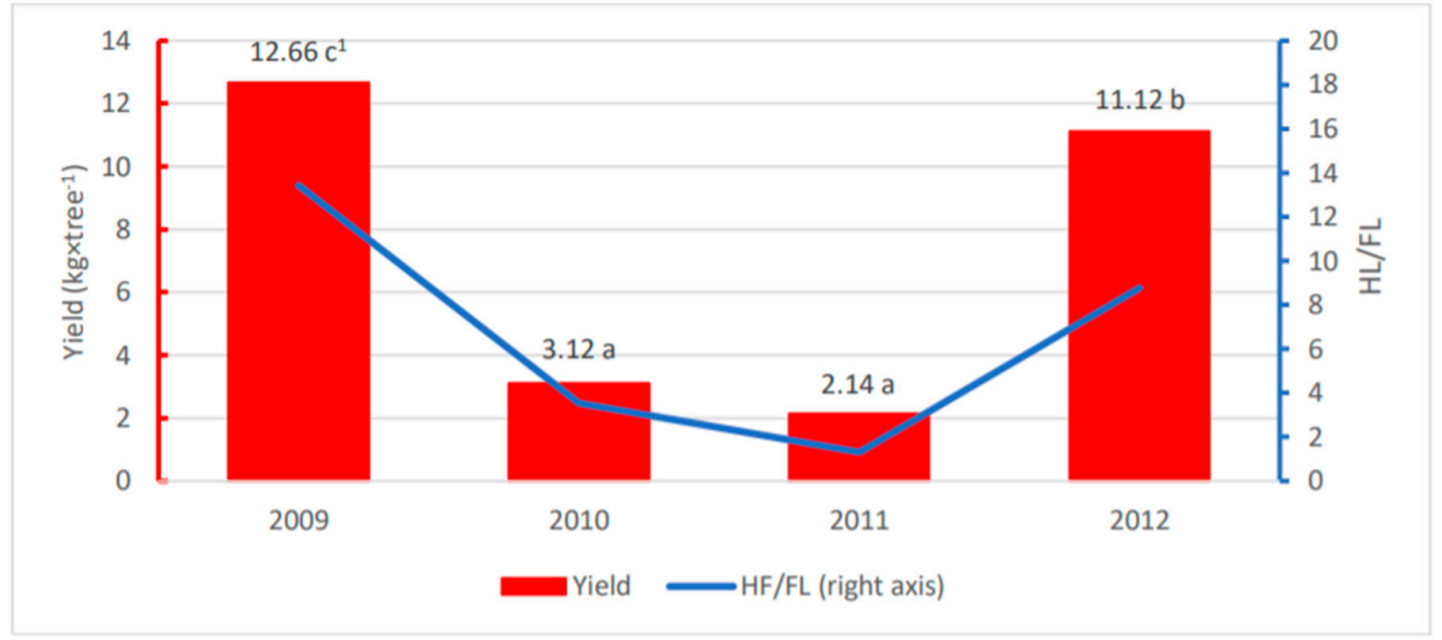

Figure 3. Mean yields of 'Regina' sweet cherry trees in 2009-2012 and percentage of harvested fruit to the number of flowers ratio (HF/FL). ${ }^{1}$ one-way analyses of variance; data in bars marked with the same letter are not significantly different at $\alpha=0.05$ (Duncan's test).
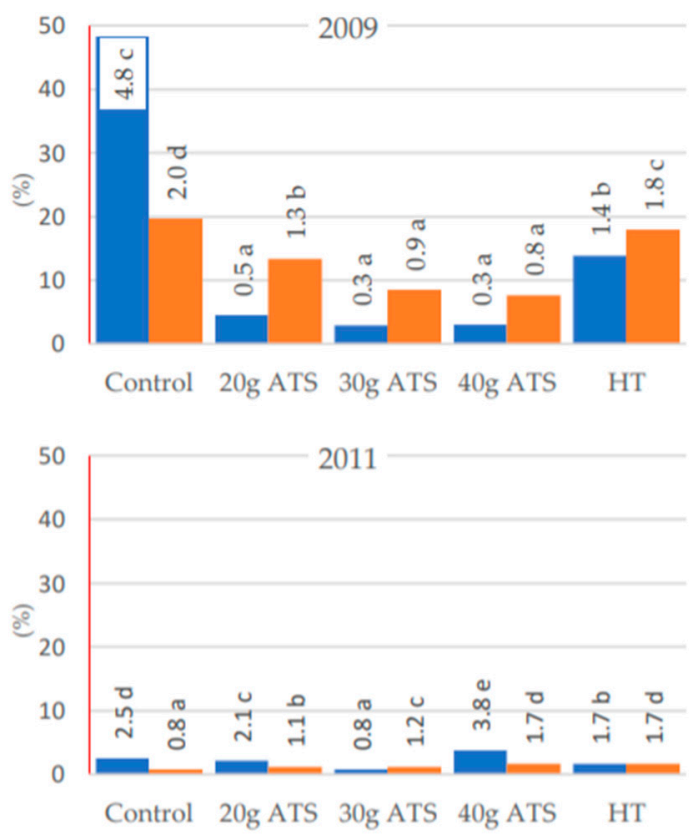
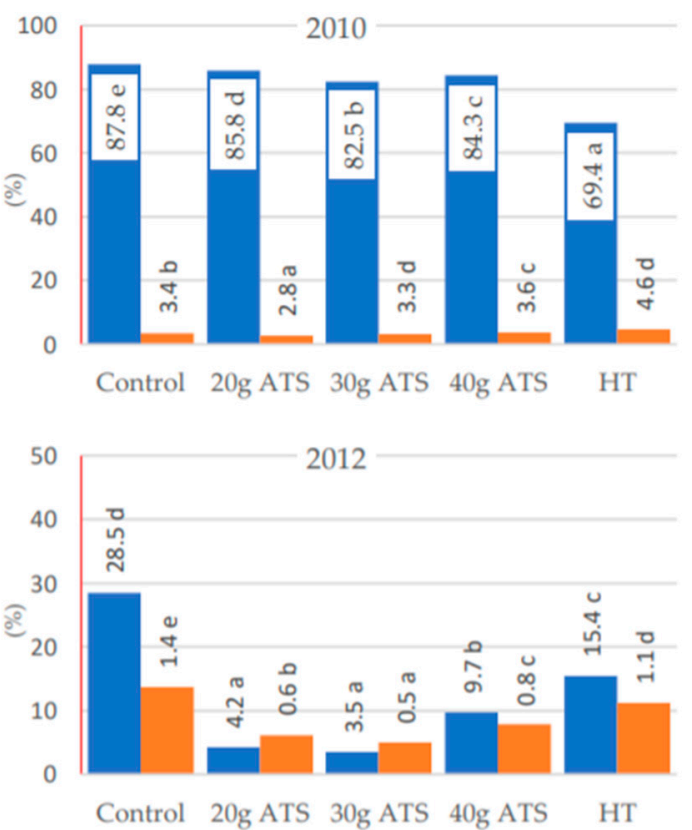

Figure 4. The effect of thinning on fruit set and fruit drop of Regina sweet cherry trees in 2009-2012.

${ }^{1}$ one-way analyses of variance; data in bars of the same colour, marked with the same letter, are not significantly different at $\alpha=0.05$ (Duncan's test).

ATS applications were found to have an impact on tree yields in 2009 and 2012 (Table 4). Chemical thinning of flowers resulted in a yield decrease by $29.4 \%$ at $20 \mathrm{~g}$ ATS, by $43.0 \%$ at $30 \mathrm{~g}$ ATS and by $48.9 \%$ at $40 \mathrm{~g}$ ATS. No effect of hand thinning was observed. In 2012, yield differences ranged from $15.7 \%$ to $41.5 \%$, but a significant difference was found only after the application of ATS at a dose of $40 \mathrm{~g}$ (Table 4). The literature mentions a similar effect after applying 2\% ATS to 'Bing'/'Gisela 5' cherries [36]. In other studies, ATS was effective with 20.4 or $30.6 \mathrm{~g} \mathrm{~L}^{-1}$, while the dose of $10.2 \mathrm{~g} \mathrm{~L}^{-1}$ had no effect on the fruit set [49]. ATS effectiveness on crop was also confirmed by studies conducted in Switzerland on four self-sterile varieties of cherries [37]. 
Table 4. The effect of thinning on productivity parameters of Regina sweet cherry trees in 2009-2012.

\begin{tabular}{|c|c|c|c|c|c|c|c|}
\hline Treatment & \multicolumn{2}{|c|}{$\begin{array}{l}\text { Yield per Tree } \\
\left(\mathrm{kg} \mathrm{tree}^{-1}\right)\end{array}$} & $\begin{array}{l}\text { Yield per Area } \\
\quad\left(\mathrm{t} \mathrm{ha} \mathbf{a}^{-1}\right)\end{array}$ & \multicolumn{2}{|c|}{$\begin{array}{l}\text { Yield Efficiency (kg of } \\
\left.\text { Fruit per cm } \mathrm{TCSA}^{2}\right) \\
\qquad\left(\mathrm{kg} \mathrm{cm}^{-2}\right)\end{array}$} & \multicolumn{2}{|c|}{$\begin{array}{c}\text { Yield to Total } \\
\text { 1-Year-Old Shoot } \\
\text { Length (TSL) }\left(\mathrm{kg} \mathrm{m}^{-1}\right)\end{array}$} \\
\hline \multicolumn{8}{|c|}{2009} \\
\hline Control & 17.3 & $\mathrm{c}^{1}$ & 24.7 & 0.23 & c & 1.17 & $\mathrm{~d}$ \\
\hline $20 \mathrm{~g}$ ATS & 12.2 & $\mathrm{~b}$ & 17.4 & 0.17 & $\mathrm{~b}$ & 0.65 & $\mathrm{~b}$ \\
\hline $30 \mathrm{~g}$ ATS & 9.9 & $\mathrm{ab}$ & 14.1 & 0.13 & $\mathrm{a}$ & 0.41 & a \\
\hline $40 \mathrm{~g}$ ATS & 8.8 & $\mathrm{a}$ & 12.6 & 0.10 & a & 0.31 & a \\
\hline Hand thinning & 15.1 & $\mathrm{c}$ & 21.6 & 0.20 & $\mathrm{bc}$ & 0.96 & c \\
\hline \multicolumn{8}{|c|}{2010} \\
\hline Control & 2.5 & $\mathrm{~b}$ & 3.6 & 0.03 & a & 0.06 & a \\
\hline $20 \mathrm{~g}$ ATS & 3.4 & $\mathrm{a}$ & 4.8 & 0.04 & $\mathrm{~b}$ & 0.08 & $\mathrm{~b}$ \\
\hline $30 \mathrm{~g}$ ATS & 3.4 & $\mathrm{a}$ & 4.9 & 0.03 & $\mathrm{a}$ & 0.09 & $\mathrm{bc}$ \\
\hline $40 \mathrm{~g}$ ATS & 3.5 & $\mathrm{a}$ & 5.0 & 0.03 & a & 0.10 & c \\
\hline Hand thinning & 2.8 & $\mathrm{~b}$ & 3.9 & 0.03 & $\mathrm{a}$ & 0.08 & $\mathrm{~b}$ \\
\hline \multicolumn{8}{|c|}{2011} \\
\hline Control & 1.3 & $\mathrm{a}$ & 1.9 & 0.01 & $\mathrm{a}$ & 0.03 & $\mathrm{a}$ \\
\hline $20 \mathrm{~g}$ ATS & 3.0 & c & 4.2 & 0.03 & c & 0.05 & c \\
\hline $30 \mathrm{~g}$ ATS & 1.5 & a & 2.2 & 0.01 & a & 0.03 & $\mathrm{a}$ \\
\hline $40 \mathrm{~g}$ ATS & 2.8 & c & 4.1 & 0.02 & $\mathrm{~b}$ & 0.05 & c \\
\hline Hand thinning & 2.1 & $\mathrm{~b}$ & 3.1 & 0.02 & $\mathrm{~b}$ & 0.04 & $\mathrm{~b}$ \\
\hline \multicolumn{8}{|c|}{2012} \\
\hline Control & 13.7 & c & 19.5 & 0.11 & c & 0.25 & c \\
\hline $20 \mathrm{~g}$ ATS & 11.5 & $\mathrm{~b}$ & 16.4 & 0.10 & $\mathrm{bc}$ & 0.22 & $\mathrm{bc}$ \\
\hline $30 \mathrm{~g}$ ATS & 10.9 & $\mathrm{~b}$ & 15.6 & 0.07 & $\mathrm{a}$ & 0.19 & $\mathrm{~b}$ \\
\hline $40 \mathrm{~g}$ ATS & 8.0 & $\mathrm{a}$ & 11.4 & 0.09 & $\mathrm{~b}$ & 0.14 & $\mathrm{a}$ \\
\hline Hand thinning & 11.5 & $\mathrm{~b}$ & 16.4 & 0.11 & c & 0.24 & c \\
\hline
\end{tabular}

${ }^{1}$ one-way analyses of variance; data in the same column marked with the same letter are not significantly different within a year at $\alpha=0.05$ (Duncan's test).

Yield efficiency ( $\mathrm{kg}$ of fruit $\mathrm{cm}^{-2}$ TCSA) was different in each year, and the effects of chemical thinning were significant only in 2009 and 2012 (Table 4). Thinning resulted in a decrease in yield efficiency and yield to total 1-year-old shoot length only in the full crop years.

In 2009 and 2012 chemical and manual thinning significantly influenced also the yield relative to the total length of one-year shoots. In 2009, it was the highest on control trees $\left(1.17 \mathrm{~kg} \mathrm{~m}^{-1}\right)$, significantly lower after manual thinning $\left(0.96 \mathrm{~kg} \mathrm{~m}^{-1}\right)$, even lower after chemical thinning of flowers (Table 4). In 2012, the pattern was similar, although the differences were not so clear.

The mean yield did not vary much, but was lower after $30 \mathrm{~g}$ ATS and $40 \mathrm{~g}$ ATS (Table 4). Furthermore, the thinning of flower buds of 'Bing' cherries during the dormancy period was found to have a similar effect on the yield and yield efficiency [6,9]. However, in other studies conducted on cherries, the removal of only $20 \%$ of flowers and $20 \%$ of buds significantly increased yield efficiency [26].

Thinning of flowers and fruitlets had a significant impact on the regularity of fruiting. The alternate bearing index $(\mathrm{ABI})$ was the highest on unthinned trees $(\mathrm{ABI}=0.69)$. The smallest yield fluctuations $(\mathrm{ABI}=0.35)$ were observed on trees whose flowers were thinned with $40 \mathrm{~g}$ ATS (Figure 5). Despite the opinion that cherries grown on dwarf rootstocks show less tendency towards biannual bearing compared to other fruit species [13], this study clearly showed alternate bearing in the unthinned cherry trees. However, it should be stressed that alternate bearing may be induced to a larger extent by climate conditions and agrotechnical treatments [50]. Reducing alternate bearing brings economic 
benefits [1]. Thinned trees give a lower but more regular yield, thus ensuring steady income every year. Even if unthinned trees bear a lot of fruit, prices are usually much lower due to low fruit quality (small size).
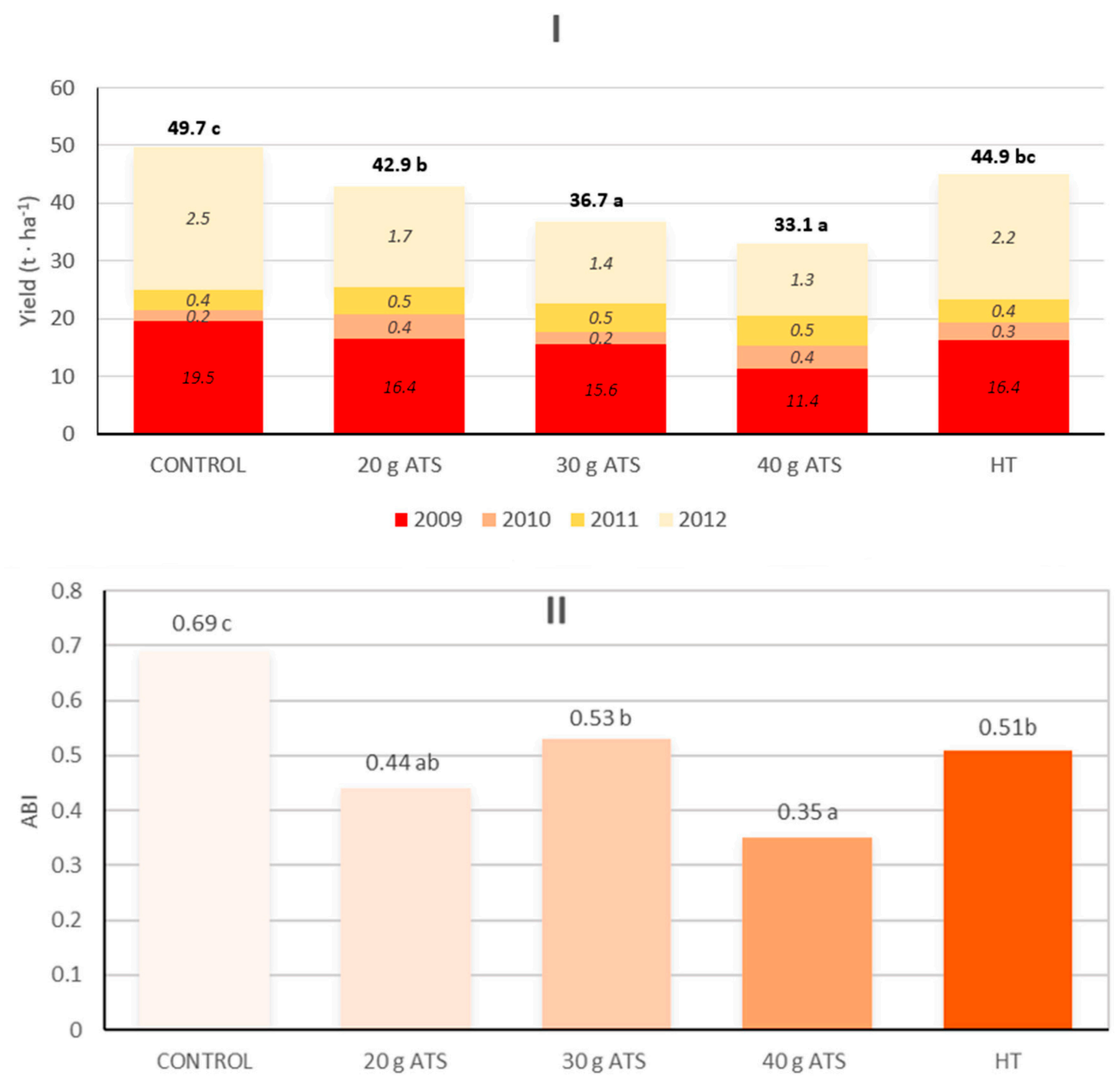

Figure 5. The effect of thinning on cumulative yield of 'Regina' sweet cherry trees in 2009-2012 (I) and alternate bearing index-ABI (II) ${ }^{1}$ One-way analyses of variance; data in bars marked with the same letter are not significantly different at $\alpha=0.05$ (Duncan's test).

\subsection{Total Soluble Solids and Acidity}

TSS and TA in the fruit depended on the year of experiment. Different courses of weather conditions and the sum of active temperatures determine not only the time of maturation, but also the chemical composition of the fruit [51]. According to earlier studies on cherries, TSS in the fruit could be more influenced by the cultivar and the course of weather conditions than by thinning operations [49] and the year [37]. Some experiments have shown that lower temperatures and heavy rainfalls can decrease the content of soluble solids in cherries. Thinning had an effect on TSS in the full crop years (2009 and 2012), whereas it affected acidity only in 2012. In 2009, the highest extract content was identified in fruit from trees treated with the two highest doses of ATS. In 2012, any thinning procedure increased TSS in the fruit. The mean TSS values for all four years of research showed a positive influence of all thinning methods on this quality trait and the increase ranged from $2.9 \%$ to $5.3 \%$ (Figure 6). This effect was already observed in previous studies $[9,12]$ and was explained by a 
lower fruit/leaf area ratio and reduced competition for assimilates between fruit. Similar conclusions were proposed by [6], who stated that fruit yield was negatively correlated with quality parameters.
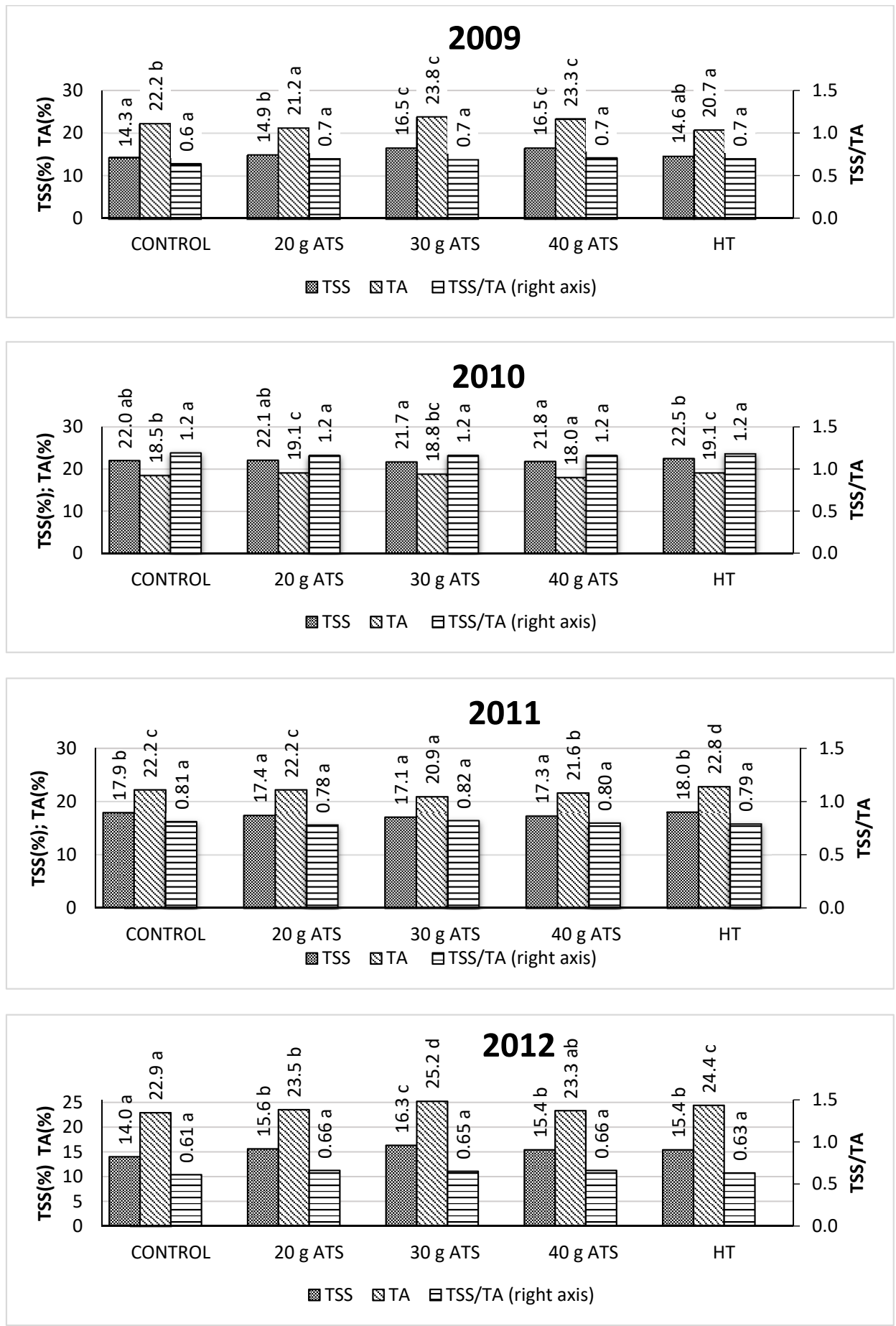

Figure 6. The effect of thinning on total soluble solids (TSS), titratable acidity (TA) and TSS/TA ratio of 'Regina' sweet cherry fruit in 2009, 2010, 2011 and 2012. ${ }^{1}$ One-way analyses of variance; data in bars filled with the same pattern, marked with the same letter, are not significantly different at $\alpha=0.05$ (Duncan's test).

As with TSS, thinning was found to affect TA in 2009 and 2012. In 2009, fruit from control trees had the lowest acidity level. In 2012, overall acidity increased in fruit from trees thinned with ATS at 
doses of $20 \mathrm{~g}$ and $40 \mathrm{~g}$. The multi-year mean value also shows that the thinning of fruit increases its overall acidity, which is in accord with some findings on the effects of flower bud thinning [52].

The TSS/TA ratio changed after all treatments only in 2012, while in 2011 after thinning with $30 \mathrm{~g}$ and $40 \mathrm{~g}$ ATS and after fruitlet hand thinning. The 4 year mean value did not show the effect of thinning on this trait (Figure 7). The influence of chemical thinning on the TSS/TA ratio had previously been demonstrated for the Japanese plum [7]. In cherry cultivation, the higher number of fruit/leave area ratio resulted in a higher TSS/TA ratio [12]. In this study, TSS and TA were positively correlated regardless of the year and treatment (correlation coefficient $=0.97$, see Figure 8).

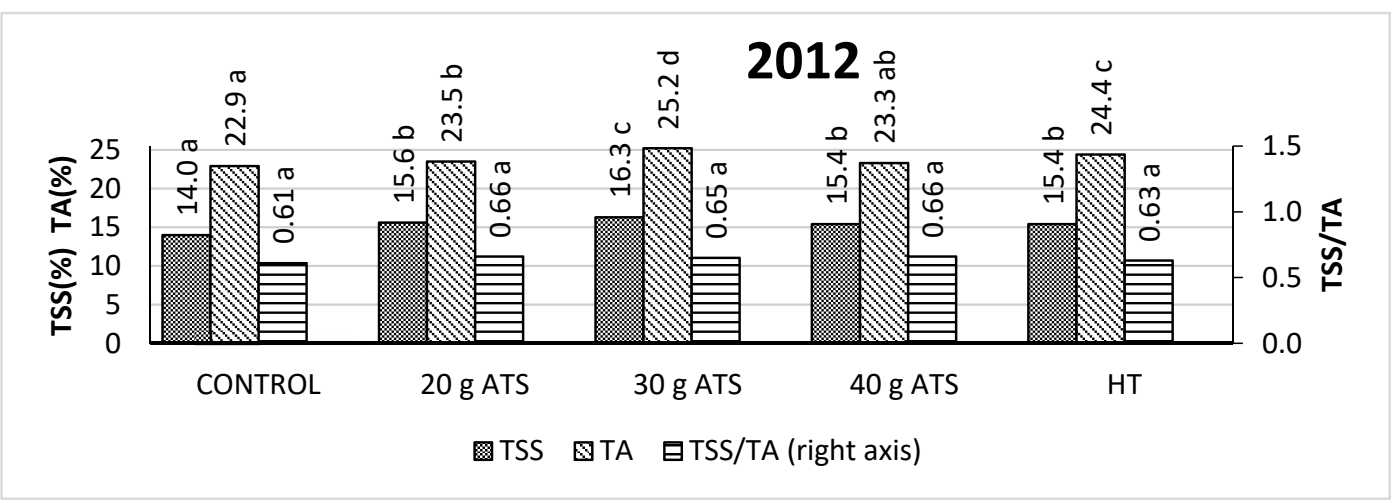

Figure 7. The effect of thinning on mean total soluble solids (TSS), titratable acidity (TA) and TSS/TA ratio of 'Regina' sweet cherry fruit in 2009-2012. ${ }^{1}$ One-way analyses of variance; data in bars filled with the same pattern, marked with the same letter, are not significantly different at $\alpha=0.05$ (Duncan's test).

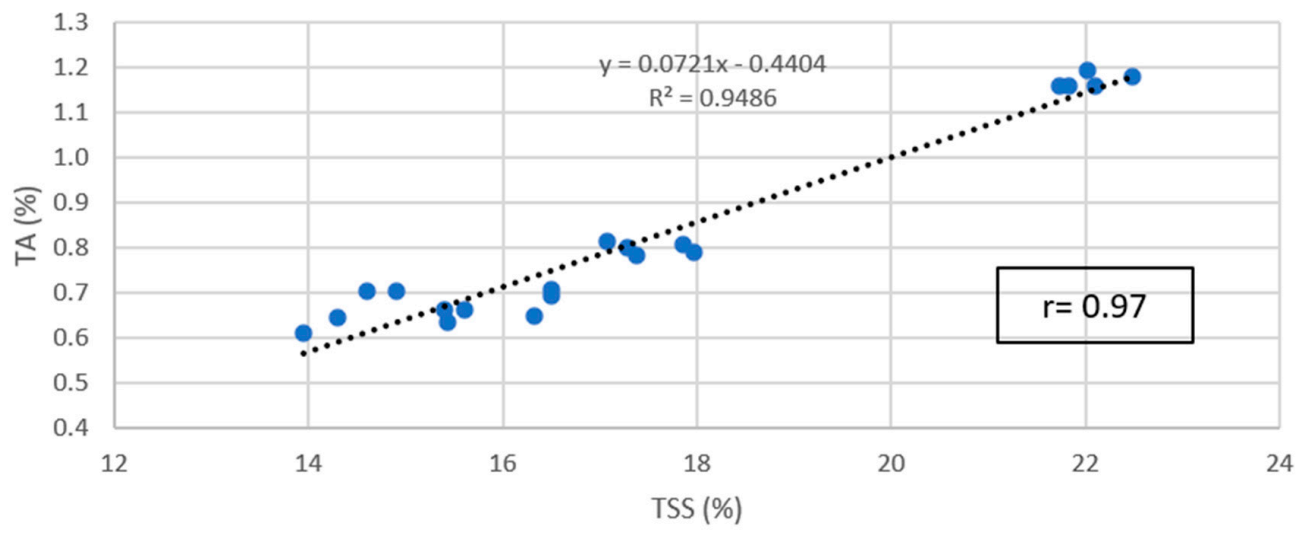

Figure 8. Correlation between total soluble solids (TSS) and titratable acidity (TA) of 'Regina' sweet cherry fruit in 2009-2012 regardless of treatment.

\subsection{Fruit Colouring}

Fruit ripening involves biochemical changes that affect the taste, firmness, colour and other quality parameters of the fruit (Bureau et al. 2009), which very often depend on the course of climatic conditions during the growing season [53]. One aspect of fruit maturation is the change in the fruit skin colour from green to red, which is due to the accumulation of anthocyanins and the degradation of chlorophyll [54]. The change in the fruit skin colour can be used as one of the basic indicators of the optimum harvest date [55]. In the present study, measurements of the fruit skin colour coordinates showed that thinning treatments had an effect on the colour of the fruit at harvest. Fruit with a significantly darker fruit skin colour $\left(\mathrm{L}^{*}\right)$ observed in 2009 and 2010 came from trees sprayed with ATS at a dose of $40 \mathrm{~g}$. This agrees with the results of thinning experiments conducted on flower buds of the 'Lapins' cherry, which revealed that fruit from thinned trees was darker regardless of treatment intensity [56]. A similar effect was achieved by intensive cherry pruning [53]. 
Thinning of buds was found to reduce the value of the $a^{*}$ coordinate [56], but in this experiment, such an effect was observed only in 2010 in fruit from trees hand thinned or sprayed with ATS at a dose of $30 \mathrm{~g}$ (Figure 9).
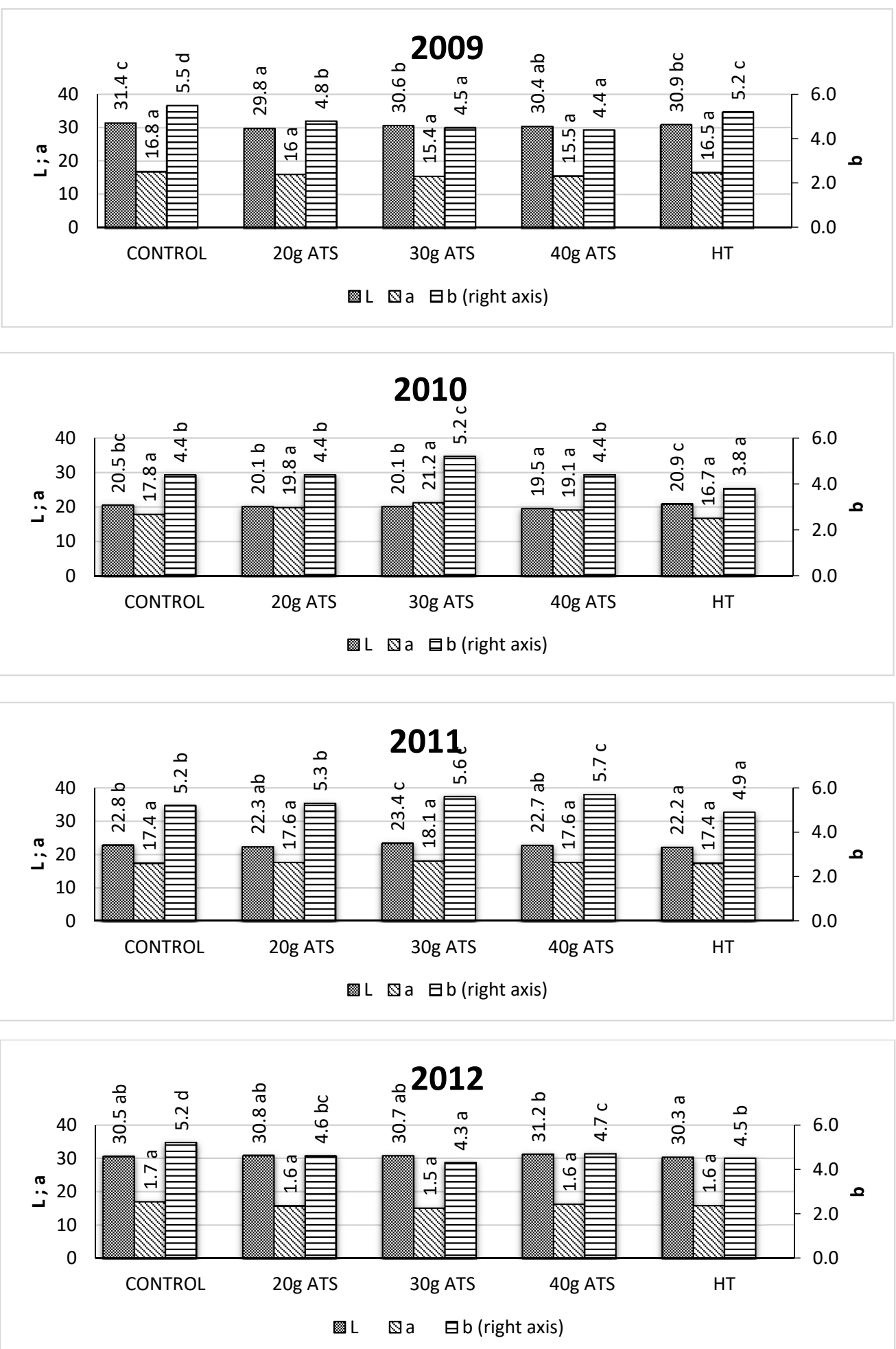

Figure 9. The effect of thinning on the colour of 'Regina' sweet cherry fruit in 2009, 2010, 2011 and 2012. ${ }^{1}$ One-way analyses of variance separate for each colour coordinate; data in bars filled with the same pattern, marked with the same letter, are not significantly different at $\alpha=0.05$ (Duncan's test). 
The hue value $\left(\mathrm{h}^{\circ}\right)$ was not influenced by thinning in any of the analysed years (Table 5). The correlation coefficient between $\mathrm{h}^{\circ}$ and TSS was negative $(-0.89)$ regardless of year and treatment (Figure 10).

Table 5. The effect of thinning on the hue value $\left(\mathrm{h}^{\circ}\right)$ of 'Regina' sweet cherry fruit-mean values for 2009-2012.

\begin{tabular}{|c|c|c|c|c|c|c|c|c|c|}
\hline \multirow{2}{*}{$\begin{array}{c}\text { Treatment } \\
\text { Control }\end{array}$} & \multicolumn{2}{|c|}{2009} & \multicolumn{2}{|c|}{2010} & \multicolumn{2}{|c|}{2011} & \multicolumn{2}{|c|}{2012} & \multirow{2}{*}{$\begin{array}{c}\text { Mean } \\
\text { 2009-2012 } \\
16.4\end{array}$} \\
\hline & 18.0 & $\mathrm{~d}^{1}$ & 13.8 & c & 16.8 & $\mathrm{~b}$ & 17.1 & c & \\
\hline $20 \mathrm{~g}$ ATS & 16.8 & $b$ & 12.6 & a & 16.8 & $\mathrm{~b}$ & 16.4 & $\mathrm{~b}$ & 15.7 \\
\hline $30 \mathrm{~g}$ ATS & 16.2 & $\mathrm{a}$ & 13.7 & c & 17.0 & $\mathrm{~b}$ & 16.0 & $\mathrm{a}$ & 15.7 \\
\hline $40 \mathrm{~g}$ ATS & 15.9 & $\mathrm{a}$ & 13.0 & $\mathrm{~b}$ & 17.8 & $\mathrm{c}$ & 16.1 & $\mathrm{ab}$ & 15.7 \\
\hline Hand thinning & 17.5 & $\mathrm{c}$ & 12.8 & $a b$ & 15.7 & $\mathrm{a}$ & 15.9 & $\mathrm{a}$ & 15.5 \\
\hline Annual mean value & 16.9 & & 13.2 & & 16.8 & & 16.3 & & \\
\hline
\end{tabular}

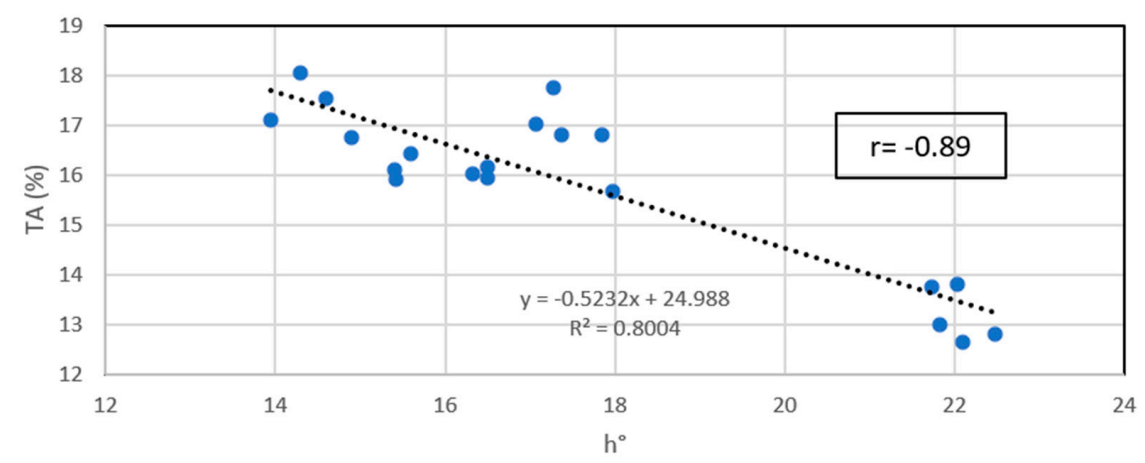

Figure 10. Correlation between total soluble solids (TSS) of 'Regina' sweet cherry fruit and $h^{\circ}$ in 2009-2012 regardless of treatment.

\subsection{Fruit Firmness}

Fruit firmness at harvest varied across the years of study, with the highest firmness value observed in $2010\left(347.0 \mathrm{~g} \mathrm{~cm}^{-1}\right)$ and the lowest in $2012\left(248.9 \mathrm{~g} \mathrm{~cm}^{-1}\right)$. Chemical thinning at $30 \mathrm{~g}$ and $40 \mathrm{~g}$ ATS increased fruit firmness in each year (Table 6). This is consistent with studies where mechanical removal of flower buds resulted in higher firmness of fruit [52]. Other studies also show that reducing the yield increases the size, TSS content and the firmness of sweet cherries [9]. The removal of spurs during tree dormancy contributed to the crop size reduction and increased fruit firmness [57]. A comparison of yields after different levels of mechanical thinning of cherry buds and flowers $(20 \%, 50 \%$ and $80 \%$ of the buds removed) revealed that a higher yield was related to a lower fruit quality and a delay in maturation [26].

Table 6. The effect of thinning on 'Regina' fruit firmness: mean values for 2009-2012.

\begin{tabular}{ccccccccccc}
\hline Treatment & \multicolumn{2}{c}{$\mathbf{2 0 0 9}$} & \multicolumn{2}{c}{$\mathbf{2 0 1 0}$} & & $\mathbf{2 0 1 1}$ & & 2012 & Mean 2009-2012 \\
\hline Control & 325.4 & $\mathrm{~b}^{1}$ & 346.7 & $\mathrm{bc}$ & 288.2 & $\mathrm{a}$ & 247.2 & $\mathrm{~b}$ & 301.5 \\
20 g ATS & 325.1 & $\mathrm{~b}$ & 340.0 & $\mathrm{ab}$ & 290.9 & $\mathrm{ab}$ & 239.7 & $\mathrm{a}$ & 298.9 \\
30 g ATS & 333.5 & $\mathrm{c}$ & 350.1 & $\mathrm{c}$ & 296.9 & $\mathrm{bc}$ & 261.7 & $\mathrm{~d}$ & 316.8 \\
40 g ATS & 311.8 & $\mathrm{a}$ & 359.3 & $\mathrm{~d}$ & 294.6 & $\mathrm{ab}$ & 253.3 & $\mathrm{c}$ & 304.8 \\
Hand thinning & 323.1 & $\mathrm{~b}$ & 337.3 & $\mathrm{a}$ & 302.9 & $\mathrm{c}$ & 242.5 & $\mathrm{ab}$ & 301.5 \\
Annual mean value & 324.7 & & 347.0 & & 294.7 & & 248.9 & & \\
\hline
\end{tabular}

${ }^{1}$ one-way analyses of variance; data in the same column marked with the same letter are not significantly different within a year at $\alpha=0.05$ (Duncan's test). 


\subsection{Fruit Size}

Fruit size is the basic qualitative criterion of cherries determining their price [1]. The thinning procedures had an impact on this trait, i.e., improved the quality of yield, but only in years when there was no frost damage. In 2009, thinning increased the share of fruit with a diameter of more than $28 \mathrm{~mm}$ (Table 7). Fruit below $26 \mathrm{~mm}$ accounted for $24 \%$ of total fruit on the control trees, while any thinning treatment reduced the share of small and medium fruit to less than $10 \%$. Whiting and Ophardt [13] pointed out that manual thinning of flowers could be used as a reliable method to increase the share of premium fruit (diameters above $26.5 \mathrm{~mm}$ ). Furthermore, chemical thinning eliminated the smallest fruit below $21.5 \mathrm{~mm}$ while increasing the share of fruit above $26.5 \mathrm{~mm}$ by more than $400 \%$ [36]. In our study, over $90 \%$ of fruit collected from thinned trees in both 2009 and 2012 was large and very large (over $26 \mathrm{~mm}$ in diameter) (Tables 7 and 8 ).

Table 7. The effect of thinning on the percentage of size categories of 'Regina' sweet cherry fruit (based on fruit diameter) in 2009.

\begin{tabular}{ccccccccccc}
\hline \multirow{2}{*}{$\begin{array}{c}\text { Fruit Diameter } \\
(\mathbf{m m})\end{array}$} & \multicolumn{8}{c}{ Fruit Percentage According to Size Categories (\%) } \\
\cline { 2 - 9 } & \multicolumn{2}{c}{ Control } & $\mathbf{2 0}$ g ATS & $\mathbf{3 0}$ g ATS & $\mathbf{4 0}$ g ATS & Hand Thinning \\
\hline$<22 \mathrm{~mm}$ & 0 & $\mathrm{a}^{1}$ & 0 & $\mathrm{a}$ & 0 & $\mathrm{a}$ & 0 & $\mathrm{a}$ & 0 & $\mathrm{a}$ \\
$22-24 \mathrm{~mm}$ & 4 & $\mathrm{~b}$ & 0 & $\mathrm{a}$ & 0 & $\mathrm{a}$ & 0 & $\mathrm{a}$ & 0 & $\mathrm{a}$ \\
$24-26 \mathrm{~mm}$ & 20 & $\mathrm{e}$ & 9 & $\mathrm{~d}$ & 2 & $\mathrm{c}$ & 0 & $\mathrm{a}$ & 1 & $\mathrm{~b}$ \\
$26-28 \mathrm{~mm}$ & 49 & $\mathrm{c}$ & 40 & $\mathrm{~b}$ & 26 & $\mathrm{a}$ & 25 & $\mathrm{a}$ & 57 & $\mathrm{~d}$ \\
$28-30 \mathrm{~mm}$ & 27 & $\mathrm{a}$ & 48 & $\mathrm{c}$ & 58 & $\mathrm{~d}$ & 60 & $\mathrm{e}$ & 39 & $\mathrm{~b}$ \\
$>30 \mathrm{~mm}$ & 0 & $\mathrm{a}$ & 3 & $\mathrm{~b}$ & 14 & $\mathrm{c}$ & 15 & $\mathrm{c}$ & 3 & $\mathrm{~b}$ \\
\hline
\end{tabular}

${ }^{1}$ one-way analyses of variance; data in the same row marked with the same letter are not significantly different at $\alpha=0.05$ (Duncan's test).

Table 8. The effect of thinning on the percentage of size categories of 'Regina' sweet cherry fruit (based on fruit diameter) in 2012.

\begin{tabular}{|c|c|c|c|c|c|c|c|c|c|c|}
\hline \multirow{3}{*}{$\begin{array}{c}\begin{array}{c}\text { Fruit Diameter } \\
(\mathbf{m m})\end{array} \\
<22 \mathrm{~mm}\end{array}$} & \multicolumn{10}{|c|}{ Fruit Percentage in Size Categories (\%) } \\
\hline & \multicolumn{2}{|c|}{ Control } & \multicolumn{2}{|c|}{$20 \mathrm{~g}$ ATS } & \multicolumn{2}{|c|}{30 g ATS } & \multicolumn{2}{|c|}{$40 \mathrm{~g}$ ATS } & \multicolumn{2}{|c|}{ Hand thinning } \\
\hline & 0 & $a^{1}$ & 0 & $\mathrm{a}$ & 0 & a & 0 & a & 0 & a \\
\hline $22-24 \mathrm{~mm}$ & 1 & $\mathrm{~b}$ & 1 & $\mathrm{~b}$ & 0 & a & 0 & a & 0 & $\mathrm{a}$ \\
\hline $24-26 \mathrm{~mm}$ & 32 & $\mathrm{~d}$ & 5 & a & 8 & c & 5 & $\mathrm{a}$ & 6 & $\mathrm{~b}$ \\
\hline $26-28 \mathrm{~mm}$ & 47 & $\mathrm{~d}$ & 38 & c & 48 & $\mathrm{e}$ & 37 & $\mathrm{~b}$ & 29 & $\mathrm{a}$ \\
\hline $28-30 \mathrm{~mm}$ & 20 & $\mathrm{a}$ & 54 & $\mathrm{e}$ & 35 & $\mathrm{~b}$ & 49 & $\mathrm{c}$ & 52 & $\mathrm{~d}$ \\
\hline$>30 \mathrm{~mm}$ & 0 & $\mathrm{a}$ & 2 & $\mathrm{~b}$ & 9 & $c$ & 9 & $\mathrm{c}$ & 13 & $\mathrm{~d}$ \\
\hline
\end{tabular}

${ }^{1}$ one-way analyses of variance; data in the same row marked with the same letter are not significantly different at $\alpha=0.05$ (Duncan's test).

\subsection{Vegetative Tree Growth Parameters}

According to literature, fruiting and vegetative growth are negatively correlated [58]. Competition between fruit and leaves for nutrients significantly weakens growth in years of abundant yield [59]. In the present study, the strength and nature of vegetative growth were assessed based on the measurements of the number and length of one-year shoots and the trunk cross-sectional area (Table 9). 
Table 9. The effect of thinning on vigour parameters of 'Regina' sweet cherry trees in 2009-2012.

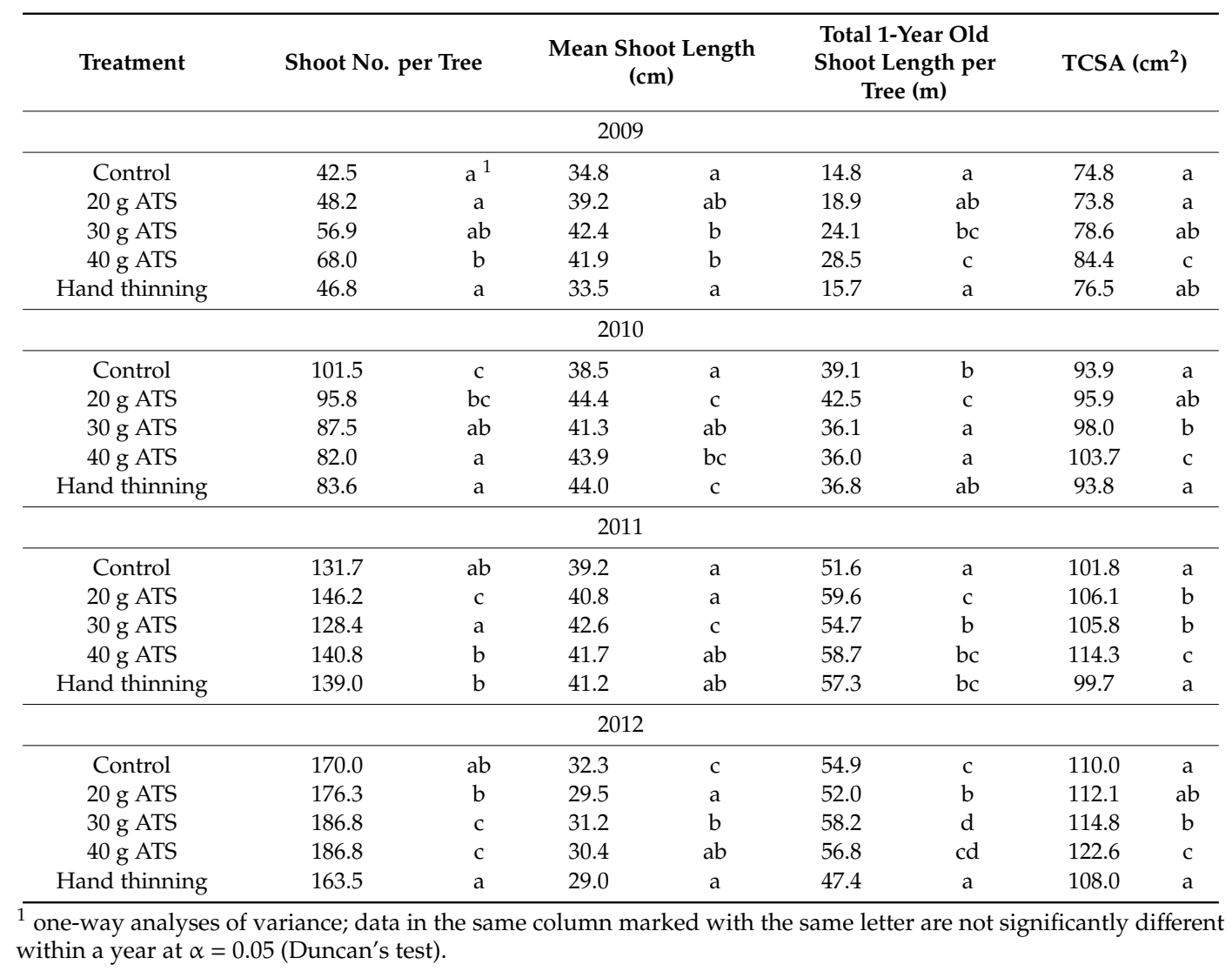

The mean annual number of shoots per tree in 2009 ranged from 42.5 to 68 . Trees whose fruit was not thinned at all and which had the highest yield had the smallest number of shoots (Table 9). Numerous shoots ending with a flower bud are desirable on the tree, as they allow growers to maintain high productivity levels. In the following year, which due to a poor fruit setting was a year of poor yield, excessive growth was observed on unthinned trees, which was manifested in the largest number of shoots (over 100) (Table 9). In 2012, when the yield was high and the impact of thinning could be seen in all parameters measured, the number of shoots on unthinned trees was lower than on trees treated with ATS. Other important parameters characterizing tree vigour are the mean shoot length and total shoot length per tree $[60,61]$. When it comes to the mean shoot length, the 2009 results revealed the shortest shoots on trees thinned by hand, and the longest on trees thinned with ATS at doses of $30 \mathrm{~g}$ and $40 \mathrm{~g}$. The total length of one-year shoots of $14.8 \mathrm{~m}$ and $15.7 \mathrm{~m}$, respectively, in the control and manually thinned trees was significantly lower than on trees thinned with $40 \mathrm{~g}$ ATS $(28.5 \mathrm{~m})$. In 2010 and 2011, the differences in the length of shoots were smaller than in the full crop years, in which flowers were not damaged by frosts. The vigour of the tree measured by trunk cross-sectional area was also varied depending of the year of experiment. In the full crop years, the trunk grew most strongly on trees thinned with ATS at a dose of $40 \mathrm{~g}$. (Table 9). Stronger vegetative growth of trees with a lower yield as a result of thinning is confirmed by other studies where non-fruiting cherry trees were characterized by a stronger increase in the number of shoots and a larger leaf area [62]. However, another experiment involving spur thinning showed that thinning influenced the leaf area, but had no effect on the length of shoots [63]. Undoubtedly, thinning treatments visibly affect tree growth; however, depending on the thinning method, timing, weather conditions prevailing in a given year and thinning agent dosage, the effect can be observed on different tree vigour parameters. 


\section{Conclusions}

Every thinning method has advantages and disadvantages. However, if a method produces the assumed results, it is worth implementing on a larger scale. Mechanical thinning, which is becoming more and more popular, is difficult to apply to cherries due to the size of trees and the risk of increased spread of diseases. Cherry trees are sensitive to bacterial canker $[64,65]$ and mechanical thinning may significantly increase the risk of canker infection as a result of mechanical damage to leaves and shoots. The same negative impact of mechanical thinning has been observed in apple and pear orchards that experience fireblight infections, and therefore, mechanical thinning is not recommended in plantations that have been infected with E. amylovora within the last 3 years [66]. The above-described drawback can be avoided by using such chemical substances which are cheap, most preferably environment-, user- and consumer-friendly [32] and do not require additional equipment. Many preparations have been withdrawn from the market for environmental reasons in recent years [67]. ATS is one of the substances still in use because it is safe for the environment and consumer [68]. This environmentally friendly compound is a cheap and easily available foliar fertilizer [69] and shows very good results in the thinning of pome species [70]. It burns the sensitive parts of flowers and destroys the stigma thus preventing pollen germination and flower pollination [32]. Its efficiency depends on weather conditions [68]. In apples, the efficiency of ATS varies depending on dosage and cultivar [71].

Climatic conditions have a significant impact on the growth and yield of cherry trees. Low temperatures during flowering reduce yield, but yield can also be negatively affected by frosts in winter and relatively low (although still positive) temperatures during fruit fertilization and initial growth. Chemical thinning of flowers significantly reduces the yield, which is particularly well illustrated by the significantly lower yield parameters. The use of ATS for thinning flowers is an effective method to regulate fruiting, as shown by the alternate bearing index, whose value was the lowest after using ATS at a dose of $40 \mathrm{~g}$. The thinning treatments used in the experiment affected fruit quality, but only in years of full crop. Total soluble solids and titratable acidity increased as a result of thinning. At the same time, fruit colour and TSS were found to be negatively correlated. The use of ATS allowed the achievement of a darker fruit. Chemical thinning improved fruit quality in the years of full crop and resulted in a higher share of large and very large fruit in the total yield. The vegetative growth of trees was the strongest after applying the highest dose of ATS $(40 \mathrm{~g})$ in the years of full crop.

Author Contributions: Conceptualization, R.K.; methodology, R.K.; software, R.K. and K.R.; validation, R.K. and K.R.; and G.P.Ł.; formal analysis K.R. and G.P.Ł.; investigation, R.K.; resources, R.K. and K.R.; data curation, R.K. and K.R writing — original draft preparation, R.K. and K.R.; writing—review and editing, K.R. and G.P.Ł.; visualization, R.K. and K.R.; supervision, G.P.Ł.; project administration, R.K.; funding acquisition, K.R. and G.P.Ł. All authors have read and agreed to the published version of the manuscript.

Funding: This research received no external funding.

Conflicts of Interest: The authors declare no conflict of interest. The funders had no role in the design of the study; in the collection, analyses, or interpretation of data; in the writing of the manuscript, or in the decision to publish the results.

\section{References}

1. Florkowski, W.J.; Łysiak, G. Quality attribute-price relationship: Modernization of the sweet cherry sector in Poland. Sci. J. Wars. Univ. Life Sci. SGGW Probl. World Agric. 2015, 15, 41-55. [CrossRef]

2. Stehr, R. Further experiences with dwarfing sweet cherry rootstocks in Northern Germany. Acta Hortic. 2008, 185-190. [CrossRef]

3. Usenik, V.; Stampar, F.; Fajt, N. Sweet cherry rootstock testing in Slovenia. Acta Hortic. 2008, 795, $273-276$. [CrossRef]

4. Whiting, M.D.; Lang, G.; Ophardt, D. Rootstock and training system affect sweet cherry growth, yield, and fruit quality. HortScience 2005, 40, 582-586. [CrossRef]

5. Byers, R.E.; Costa, G.; Vizzotto, G. Flower and fruit thinning of peach and other Prunus. In Horticultural Reviews; John Wiley \& Sons, Ltd.: Hoboken, NJ, USA, 2010; pp. 351-392. ISBN 978-0-470-65085-1. 
6. Bound, S.A.; Close, D.C.; Quentin, A.G.; Measham, P.F.; Whiting, M.D. Crop load and time of thinning interact to affect fruit quality in sweet cherry. J. Agric. Sci. 2013, 5, 216-230. [CrossRef]

7. Rajput, V.; Bhatia, S.K. Changes in fruit quality parameters in Japanese plum cv. Kala Amritsari with chemical flower thinning. J. Pharmacogn. Phytochem. 2017, 6, 2220-2223.

8. Miller, S.S.; Schupp, J.R.; Baugher, T.A.; Wolford, S.D. Performance of mechanical thinners for bloom or green fruit thinning in peaches. HortScience 2011, 46, 43-51. [CrossRef]

9. Whiting, M.D.; Lang, G.A. 'Bing' Sweet Cherry on the Dwarfing Rootstock 'Gisela 5': Thinning Affects Fruit Quality and Vegetative Growth But not Net $\mathrm{CO}_{2}$ Exchange. J. Amer. Soc. Hort. Sci. 2004, 407-415. [CrossRef]

10. Reginato, G.H.; Robinson, T.L.; Yoon, T.M. Improving cherry fruit size of self-fertile cultivars in NY orchards. N. Y. Fruit Q. 2008, 16, 27-30.

11. Lauri, P.E.; Claverie, J. Sweet Cherry Training to Improve Fruit Size and Quality-An Overview of Some Recent Concepts and Practical Aspects; Acta Horticulturae: Leuven, Belgium, 2005; Volume 667.

12. Usenik, V.; Orazem, P.; Stampar, F. Low leaf to fruit ratio delays fruit maturity of 'Lapins' sweet cherry on Gisela 5. Sci. Hortic. 2010, 126, 33-36. [CrossRef]

13. Whiting, M.D.; Ophardt, D. Comparing novel sweet cherry crop load management strategies. HortScience 2005, 40, 1271-1275. [CrossRef]

14. Gonçalves, B.; Silva, A.P.; Moutinho-Pereira, J.; Bacelar, E.; Rosa, E.; Meyer, A.S. Effect of ripeness and postharvest storage on the evolution of colour and anthocyanins in cherries (Prunus avium L.). Food Chem. 2007, 103, 976-984. [CrossRef]

15. Ağlar, E.; Saraçoğlu, O.; Karakaya, O.; Ozturk, B.; Gun, S. The relationship between fruit color and fruit quality of sweet cherry (Prunus avium L. cv. '0900 Ziraat'). Turk. J. Food Agric. Sci. 2019, 1, 1-5.

16. Westwood, M.N. Temperate-Zone Pomology: Physiology and Culture, 3rd ed.; Timber Press Inc.: Portland, OR, USA, 1993; ISBN 0-88192-253-6.

17. Martin-Gorriz, B.; Torregrosa, A.; García Brunton, J. Post-bloom mechanical thinning for can peaches using a hand-held electrical device. Sci. Hortic. 2012, 144, 179-186. [CrossRef]

18. Greene, D.; Costa, G. Fruit thinning in pome- and stone-fruit: State of the art. Acta Hortic. 2013, 93-102. [CrossRef]

19. Martin, P.; Calvin, L. Immigration reform: What does it mean for agriculture and rural America? Appl. Econ. Perspect. Policy 2010, 32, 232-253. [CrossRef]

20. Strijker, D. Marginal lands in Europe-Causes of decline. Basic Appl. Ecol. 2005, 6, 99-106. [CrossRef]

21. Lordan, J.; Alins, G.; Àvila, G.; Torres, E.; Carbó, J.; Bonany, J.; Alegre, S. Screening of eco-friendly thinning agents and adjusting mechanical thinning on 'Gala', 'Golden Delicious' and 'Fuji' apple trees. Sci. Hortic. 2018, 239, 141-155. [CrossRef]

22. Seehuber, C.; Damerow, L.; Kunz, A.; Blanke, M. Mechanical thinning reduces june drop and improves fruit quality i.e., fruit size of cv. 'Conference'and 'A. Lucas' pear. Erwerbs-Obstbau 2010, 45-53. [CrossRef]

23. Wang, M.; Zhang, Q.; Lewis, K.M. Parametric Study of Hand-Held Mechanical Bloom Thinner in Cherry Orchards; ASABE: St. Joseph, MI, USA, 2013; p. 1.

24. Tromp, J. Flower-bud formation in pome fruits as affected by fruit thinning. Plant Growth Regul. 2000, 31, 27-34. [CrossRef]

25. Lenahan, O.M.; Whiting, M.D. Fish oil plus lime sulfur shows potential as a sweet cherry postbloom thinning agent. HortScience 2006, 41, 860-861. [CrossRef]

26. Davarynejad, G.H.; Nyéki, J.; Szabó, T.; Szabó, Z. Influences of hand thinning of bud and blossom on crop load, fruit characteristics and fruit growth dynamic of Újfehértói fürtös sour cherry cultivar. Am. Eurasian J. Agric. Environ. Sci. 2008, 4, 138-141.

27. Costa, G.; Blanke, M.M.; Widmer, A. Principles of thinning in fruit tree crops-Needs and novelties. Acta Hortic. 2013, 17-26. [CrossRef]

28. Roubik, D.W. Pollination of Cultivated Plants: A Compendium for Practitioners, 1st ed.; Food and Agriculture Organization of the United Nations: Rome, Italy, 2018; ISBN 978-92-5-130512-6.

29. Schupp, J.R.; Auxt Baugher, T.; Miller, S.S.; Harsh, R.M.; Lesser, K.M. Mechanical thinning of peach and apple trees reduces labor input and increases fruit size. HortTechnology 2008, 18, 660-670. [CrossRef]

30. González-Rossia, D.; Reig, C.; Juan, M.; Agustí, M. Horticultural factors regulating effectiveness of GA3 inhibiting flowering in peaches and nectarines (Prunus persica L. Batsch). Sci. Hortic. 2007, 111, 352-357. [CrossRef] 
31. Stern, R.A.; Raz, A.; Applebaum, S.; Meiri, A.; Goldway, M. Uniconazole is an effective blossom thinner for 'Bing' cherry (Prunus avium). Sci. Hortic. 2009, 122, 417-420. [CrossRef]

32. Wertheim, S.J. Developments in the chemical thinning of apple and pear. Plant Growth Regul. 2000, 31, 85-100. [CrossRef]

33. Lenahan, O.; Whiting, M.; Elfving, D. Gibberellic Acid Inhibits Floral Bud Induction and Improves 'Bing' Sweet Cherry Fruit Quality. HortScience 2006, 41, 654-659. [CrossRef]

34. Southwick, S.M.; Glozer, K. Reducing flowering with gibberellins to increase fruit size in stone fruit trees: Applications and implications in fruit production. HortTechnology 2000, 10, 744-751. [CrossRef]

35. Spornberger, A.; Leder, L.; Böck, K.; Keppel, H.; Modl, P. Auswirkungen von Ausdünnungsmaßnahmen auf Ertragsparameter, Krankheitsbefall und Fruchtqualität von Süßkirschen (Prunus avium L.) unter ökologischen Anbaubedingungen. Erwerbs-Obstbau 2011, 53, 15-22. [CrossRef]

36. Whiting, M.D.; Ophardt, D.; McFerson, J.R. Chemical Blossom Thinners Vary in Their Effect on Sweet Cherry Fruit Set, Yield, Fruit Quality, and Crop Value. HortTechnology 2006, 16, 66-70. [CrossRef]

37. Schoedl, K.; Denk, A.; Hummelbrunner, S.; Modl, P.; Forneck, A. No improvement in fruit quality through chemical flower thinning in sweet cherry (Prunus avium L.). J. Sci. Food Agric. 2009, 89, 1236-1240. [CrossRef]

38. Lenahan, O.M.; Whiting, M.D. Physiological and Horticultural Effects of Sweet Cherry Chemical Blossom Thinners. HortScience 2006, 41, 1547-1551. [CrossRef]

39. Vaszily, B.; Gonda, I. Training and maintaining spindle crowns in cherry production. Int. J. Hortic. Sci. 2010, 16, 51-53. [CrossRef]

40. Monselise, S.P.; Goldschmidt, E.E. Alternate Bearing in Fruit Trees. In Horticultural Reviews; Janick, J., Ed.; John Wiley \& Sons, Inc.: Hoboken, NJ, USA, 2011; pp. 128-173. ISBN 978-1-118-06077-3.

41. Planton, G.; Edin, M. Cerise: Un code couleur pour une meilleure qualité. Infos-Ctifl 1995, 110, 9.

42. San Martino, L.; Manavella, F.A.; García, D.A.; Salato, G. Phenology and fruit quality of nine sweet cherry cultivars in South Patagonia. Acta Hortic. 2008, 841-848. [CrossRef]

43. Güler, Y.; Dikmen, F. Potential bee pollinators of sweet cherry in inclement weather conditions. J. Entomol. Res. Soc. 2013, 15, 9-19.

44. Lech, W.; Malodobry, M.; Dziedzic, E.; Bieniasz, M.; Doniec, S. Biology of sweet cherry flowering. J. Fruit Ornam. Plant Res. 2008, 16, 189-199.

45. Hedhly, A.; Hormaza, J.; Herrero, M. Effect of temperature on pollen tube kinetics and dynamics in sweet cherry, Prunus avium (Rosaceae). Am. J. Bot. 2004, 91, 558-564. [CrossRef]

46. Bieniek, A.; Kawecki, Z.; Kopytowski, J.; Zielenkiewicz, J. Yielding and fruit quality of Lithuanian sweet cherry cultivars grown under the climatic and soil conditions of Warmia. Folia Hortic. 2011, 23, 101-106. [CrossRef]

47. Salazar-Gutiérrez, M.R.; Chaves, B.; Anothai, J.; Whiting, M.; Hoogenboom, G. Variation in cold hardiness of sweet cherry flower buds through different phenological stages. Sci. Hortic. 2014, 172, 161-167. [CrossRef]

48. Rodrigo, J. Spring frosts in deciduous fruit trees-Morphological damage and flower hardiness. Sci. Hortic. 2000, 85, 155-173. [CrossRef]

49. Milić, B.; Keserović, Z.; Dorić, M.; Ognjanov, V.; Magazin, N. Fruit set and quality of self-fertile sweet cherries as affected by chemical flower thinning. Hortic. Sci. 2015, 42, 119-124. [CrossRef]

50. Pellerin, B.P.; Buszard, D.; Iron, D.; Embree, C.G.; Marini, R.P.; Nichols, D.S.; Neilsen, G.H.; Neilsen, D. A Theory of Blossom Thinning to Consider Maximum Annual Flower Bud Numbers on Biennial Apple Trees. HortScience 2011, 46, 40-42. [CrossRef]

51. Łysiak, G. The sum of active temperatures as a method of determining the optimum harvest date of 'Sampion'and 'Ligol'apple cultivars. Acta Sci. Pol. Hortorum Cultus 2012, 11, 3-13.

52. Einhorn, T.C.; Laraway, D.; Turner, J. Crop load management does not consistently improve crop value of 'Sweetheart'/'Mazzard' sweet cherry trees. HortTechnology 2011, 21, 546-553. [CrossRef]

53. Rutkowski, K.; Zydlik, Z.; Pacholak, E. Effect of tree pruning intensity on the yield and fruit quality of the sour cherry. Zemdirb. Agric. 2015, 102, 417-422. [CrossRef]

54. Pedisić, S.; Dragović-Uzelac, V.; Levaj, B.; Škevin, D. Effect of maturity and geographical region on anthocyanin content of sour cherries (Prunus cerasus var. marasca). Food Technol. Biotechnol. 2010, 48, 86-93.

55. Łysiak, G. The base colour of fruit as an indicator of optimum harvest date for two apple cultivars (Malus domestica Borkh.). Folia Hortic. 2012, 24, 81-89. [CrossRef] 
56. Landi, M.; Massai, R.; Remorini, D. Effect of rootstock and manual floral bud thinning on organoleptical and nutraceutical properties of sweet cherry (Prunus avium L.) cv 'Lapins.'. Agrochim. Pisa 2014, 58, 335-351. [CrossRef]

57. Neilsen, G.; Kappel, F.; Neilsen, D. Fertigation and crop load affect yield, nutrition, and fruit quality of 'Lapins' sweet cherry on Gisela 5 rootstock. HortScience 2007, 42, 1456-1462. [CrossRef]

58. Embree, C.G.; Myra, M.T.D.; Nichols, D.S.; Wright, A.H. Effect of blossom density and crop load on growth, fruit quality, and return bloom in 'Honeycrisp' apple. HortScience 2007, 42, 1622-1625. [CrossRef]

59. Smith, H.M.; Samach, A. Constraints to obtaining consistent annual yields in perennial tree crops. I: Heavy fruit load dominates over vegetative growth. Plant Sci. 2013, 207, 158-167. [CrossRef] [PubMed]

60. Wojcik, P.; Klamkowski, K. "Szampion" Apple Tree Response to Foliar Titanium Application. J. Plant Nutr. 2005, 27, 2033-2046. [CrossRef]

61. Webster, A.D.; Altkinson, C.J.; Lucas, A.S.; Vaughan, S.P.; Taylor, L. Interactions between root restriction, irrigation and rootstock treatments on the growth and cropping of 'Queen Cox' apple trees: Effects on orchard growth and cropping. J. Hortic. Sci. Biotechnol. 2000, 75, 181-189. [CrossRef]

62. Kappel, F. Partitioning of above-ground dry matter in 'Lambert' sweet cherry trees with or without fruit. J. Am. Soc. Hortic. Sci. 1991, 116, 201-205. [CrossRef]

63. Ayala, M.; Andrade, M.P. Effects of fruiting spur thinning on fruit quality and vegetative growth of sweet cherry (Prunus avium). Cienc. Investig. Agric. 2009, 36, 443-450. [CrossRef]

64. Spotts, R.A.; Wallis, K.M.; Serdani, M.; Azarenko, A.N. Bacterial canker of sweet cherry in Oregon-Infection of horticultural and natural wounds, and resistance of cultivar and rootstock combinations. Plant Dis. 2010, 94, 345-350. [CrossRef]

65. Thomidis, T.; Exadaktylou, E. Susceptibility of 30 cherry (Prunus avium) genotypes to the bacterium Pseudomonas syringae pv. syringae. N. Z. J. Crop Hortic. Sci. 2008, 36, 215-220. [CrossRef]

66. Ngugi, H.K.; Schupp, J.R. Evaluation of the risk of spreading fire blight in apple orchards with a mechanical string blossom thinner. HortScience 2009, 44, 862-865. [CrossRef]

67. Gonzalez, L.; Bonany, J.; Alegre, S.; Àvila, G.; Carbó, J.; Torres, E.; Recasens, I.; Martin, B.; Asin, L. Brevis thinning efficacy at different fruit size and fluorescence on 'Gala' and 'Fuji' apples. Sci. Hortic. 2019, 256, 108526. [CrossRef]

68. Janoudi, A.; Flore, J.A. Application of ammonium thiosulfate for blossom thinning in apples. Sci. Hortic. 2005, 104, 161-168. [CrossRef]

69. Costa, G.; Botton, A.; Vizzotto, G. Fruit thinning: Advances and trends. Hortic. Rev. 2018, 46, $185-226$.

70. Marchioretto, L.; Rossi, A.; Michelon, M.F.; Orlandi, J.C.; Amaral, L.O. Ammonium thiosulfate as blossom thinner in "Maxi Gala" apple trees. Pesqui. Agropecu. Bras. 2018, 53, 1132-1139. [CrossRef]

71. Fallahi, E.; Willemsen, K.M. Blossom thinning of pome and stone fruit. HortScience 2002, 37, $474-477$. [CrossRef]

(C) 2020 by the authors. Licensee MDPI, Basel, Switzerland. This article is an open access article distributed under the terms and conditions of the Creative Commons Attribution (CC BY) license (http://creativecommons.org/licenses/by/4.0/). 